\title{
The German Radar Stations at the Pointe Du Raz (FR)
}

\author{
Giancarlo T. Tomezzoli \\ Etno-Archaeological Observatory, Munich, Germany \\ Email: gt21949@gmx.de
}

How to cite this paper: Tomezzoli, G. T. (2021). The German Radar Stations at the Pointe Du Raz (FR). Archaeological Discovery, 9, 198-222.

https://doi.org/10.4236/ad.2021.93011

Received: June 23, 2021

Accepted: July 27, 2021

Published: July 30, 2021

Copyright $\odot 2021$ by author(s) and Scientific Research Publishing Inc. This work is licensed under the Creative Commons Attribution International License (CC BY 4.0).

http://creativecommons.org/licenses/by/4.0/

(c) (i) Open Access

\begin{abstract}
Because of its extension in the Atlantic Ocean, the Pointe du Raz, at the extremity of Brittany, was always an ideal place for signalisation and surveillance. For this reason, lighthouses and semaphores were activated. In the thirties of the last century, the Pointe experienced a period of prosperity that led to the construction of several hotels. It was because of the rapid German occupation of France in 1940 that the situation at the Pointe changed radically. A $2 \mathrm{~km}^{2}$ surface from the Pointe to Lescoff was requisitioned for the construction of the Stps QU 300, QU 500 and QU 13 hosting sophisticated radar stations. Various German units took turns ensuring the defence and the operations at the Pointe. On $8^{\text {th }}$ August 1944, the garrison evacuated after having set on fire and destroyed military and civilian installations. The visits on $3^{\text {rd }}$ January 2005 and $14^{\text {th }}$ August 2020 permitted to identify many Stp components and to determine their preservation state at about 75 years after the conclusion of WWII.
\end{abstract}

\section{Keywords}

WW II, Brittany, Pointe Du Raz, Radar Stations, QU 300, QU 500,

Renntier, QU 13, Radar Mammut

\section{Introduction}

Because of its extension in the Atlantic Ocean, the Pointe du Raz, at the extremity of Brittany, was always an ideal place for signalisation and surveillance. For this reason, on 1838-1839 a lighthouse was erected and from $15^{\text {th }}$ May 1839, it delivered a first order white light. In 1881 the lighthouse was completed with guardian lodgements and on 15 September 1887, it was deactivated to let place on the sea to La Vieille lighthouse. In October 1892, it was adapted to semaphore for optical signalisation operated by the French Marine Nationale (C'Est en 
France, 2020).

In the thirties of the last century, the Pointe experienced a period of prosperity that led to the construction of several hotels to lodge multitudes of visitors fascinated by its wild nature and superb panoramic visions.

It was because of the rapid German occupation of France in 1940 that the peaceful situation at the Pointe changed radically.

\section{History}

From 15 August 1940 up to January 1941, the semaphore was occupied by a detachment of a battery of the $12^{\text {th }}$ Artillery Observation Group, followed up to February 1941 by a detachment of the 6./Bataillon 151 of the Infanterie-Division 61.

A $2 \mathrm{~km}^{2}$ surface from the Pointe to Lescoff was requisitioned for the construction of radar stations (Blanchard, 2014, 2021, 2021a). The works were directed by the Organization Todt (O.T.) and the Luftwaffefeldbauamt 7. A Decauville line and trucks through the Route Nationale transported materials, sand and Ero Vili pebbles (Tomezzoli \& Marzin, 2015) for its construction. 250 - 300 French workers were daily in service at the Pointe.

On $17^{\text {th }}$ mars 1941 a Focke Wulf 200 Condor of the 2./Kampfgeswader 40, in the fog, crashed on a hamlet of Lescoff causing no civilian victims but killing three of its five crew members (Floch, 2012).

On $1^{\text {st }}$ May 1941, the semaphore was reactivated by the $01512 G$ unit of the Brest Admiralty Transmission Service.

At the end of 1941 the 25./Luftgau-Nachrichten-Regiment 12 operated a Freya and a Würzburg $39 T$ near Lescoff, in provisional, non-concrete emplacements (Blanchard, 2021a).

In 1942 the semaphore was occupied by the $01512 \mathrm{~W}$ unit of the MarineWetterwarte Brest.

The Stp. QU 300, unit $01512 F$, near the semaphore, Kriegsmarine operated, was equipped initially by $1 \times$ Würzburg 39G (Blanchard, 2021a; Le Berre, 2020), replaced on 1942 by $1 \times$ Freya SeeTakt G41g 310 FuMO 2 Calais B and $1 \times F u$ MO 214 Würzburg-See-Riese (Blanchard, 2021a; Lippmann, 2021; Danzé et al., 2017) operated by a detachment of the 1.Komp. and parts of the 31.Komp. of the Marine-Funkmeß-Abteilung 3, and by four Flak emplacements for light machine guns.

The Stp. QU 500 coded Renntier (Reindeer), at Roz-Bestrée in the middle of the Pointe, Luftwaffe operated, was equipped with $2 \times$ FuSE 65 Würzburg-Riese and $1 \times$ FuSE 80 Freya (Blanchard, 2021a; Lippmann, 2021; Danzé et al., 2017), this last replaced later by $1 \times$ FuMG-401 Freya- LZ and $1 \times$ FuSE 62D (Lippmann, 2021). Initially, $Q U 500$ was operated by a detachment of the 16./LuftgauNachrichten-Regiment 7, unit L38 089, up to December 1940. During 1941, it was operated by a detachment of the 8./34 Luftnachrichten-Regiment, unit L08 470. 
On the spring 1943, the Stp. QU 13, at Men Tan near Lescoff, Luftwaffe operated, was equipped with $1 \times$ Mammut Frederich FuMG 41/42 (Danzé et al., 2017) or $1 \times$ Mammut Caesar FuMG 41 G (cF) (Lippmann, 2021), $1 \times$ FuSE 62A on mobile carriage (Danzé et al., 2017) (Lippmann, 2021) and $1 \times$ FuMG 450 Freya (Lippmann, 2021).

$Q U 500$ and $Q U 13$ were operated by a detachment of the 25./Luftgau-NachtrichtRegiment 12, unit L42 432. On April 1943 the Regiment became the FlugmeldeLeit-Kompanie 54 and its 12.Komp., unit L55 178, was at the Pointe.

The security of the Stps was assured by 2. Artillerie-Batterie of the Flak-Gruppe 752, unit L31 782, the Landesschützen-Zug der Luftwaffe 66/IV, unit L08 889, as well as by mine fields.

An electrical factory, a water reservoir, shacks, canteens, an infirmary and a cinema projecting a new film each week were in exercise at the Pointe.

A section of the 6./Regiment 894, unit 58,135C, assumed the Pointe defence from July to October 1943. In June 1944 the defence of the coast comprising the Pointe was assumed by the 343. Infanterie Division. The 4./Regiment 898, unit $59,130 E$, assumed the Pointe defence from $5^{\text {th }}$ July 1944. A section of the $3 . / I I$. Ostbataillon (Mitte), unit 36,989, was at the Pointe. The 9./Festung-Stammtruppen $X X V$ was at the Pointe coastal sector.

On $8^{\text {th }}$ August 1944, the garrison evacuated the Pointe after having set on fire and destroyed military and civilian installations and ended up encircled in the pouch of Lezongar until it surrendered on $20^{\text {th }}$ September 1944 (Floch, 2012).

\section{The Visits}

The visits on $3^{\text {rd }}$ January 2005 and $14^{\text {th }}$ August 2020 permitted to identify many components of Qu 300,Qu 500 and Qu 13 (Figure 1).

\subsection{Qu 300}

The Qu 300 identified components (Figure 2 and Figure 3) were the following.

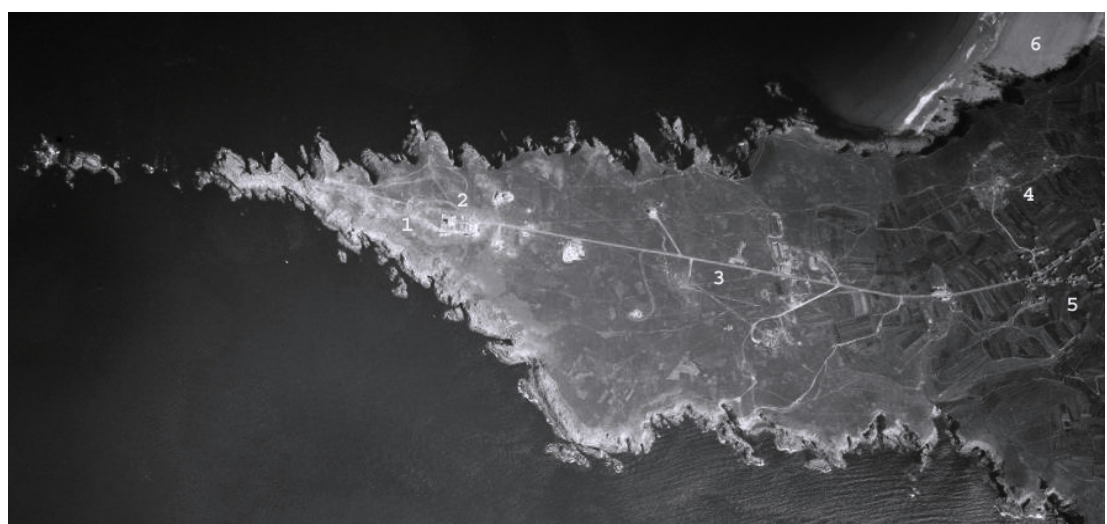

Figure 1. Stps at the Pointe du Raz-1 Qu 300; 2 semaphore; 3 Qu 500-Roz Bestrée; 4 Qu 13-Men Tan; 5 Lescoff; 6 Baie des Trépassés. [Geoportail] Image C0319-0061_ 1952_F0319-0819_0074, n74, 1/26347, Argentique, 24/05/1952. 


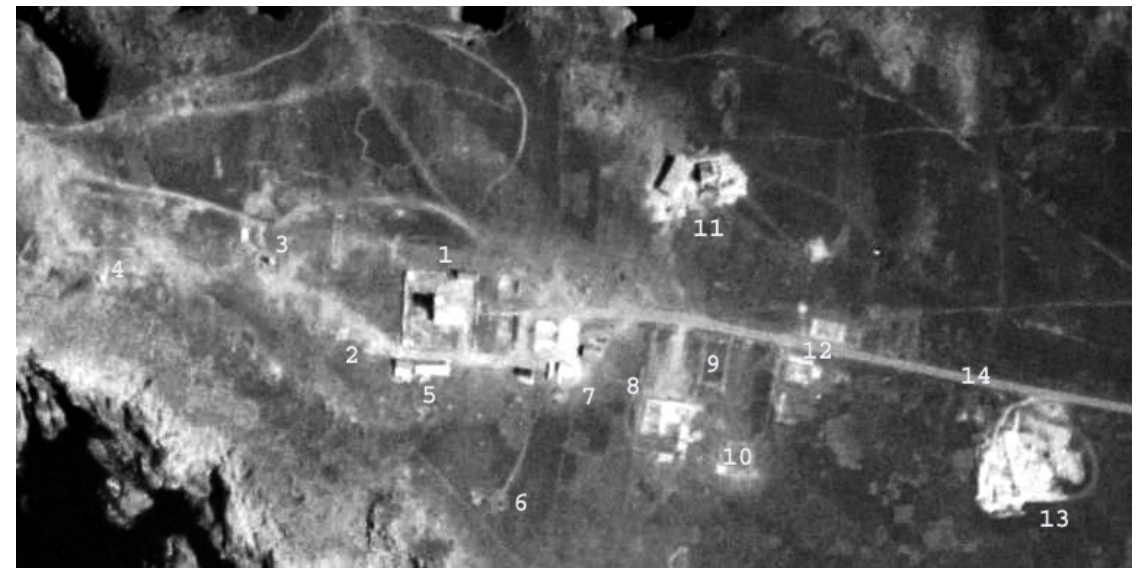

Figure 2. Qu 300-1 semaphore; 2 Würzburg and Freya emplacements; 3 Notre Dame des Naufragés monument; 4 gun emplacement; 5 shacks; 6 possible Flak emplacement; 7 hotels; 8 shacks; 9 reservoir/pool; 10 possible R622; 11 - 12 shacks; 13 heap of debris; 14 access road. [Geoportail] Image C0319-0061_1952_F0319-0819_0074, n74, 1/26347, Argentique, 24/05/1952.

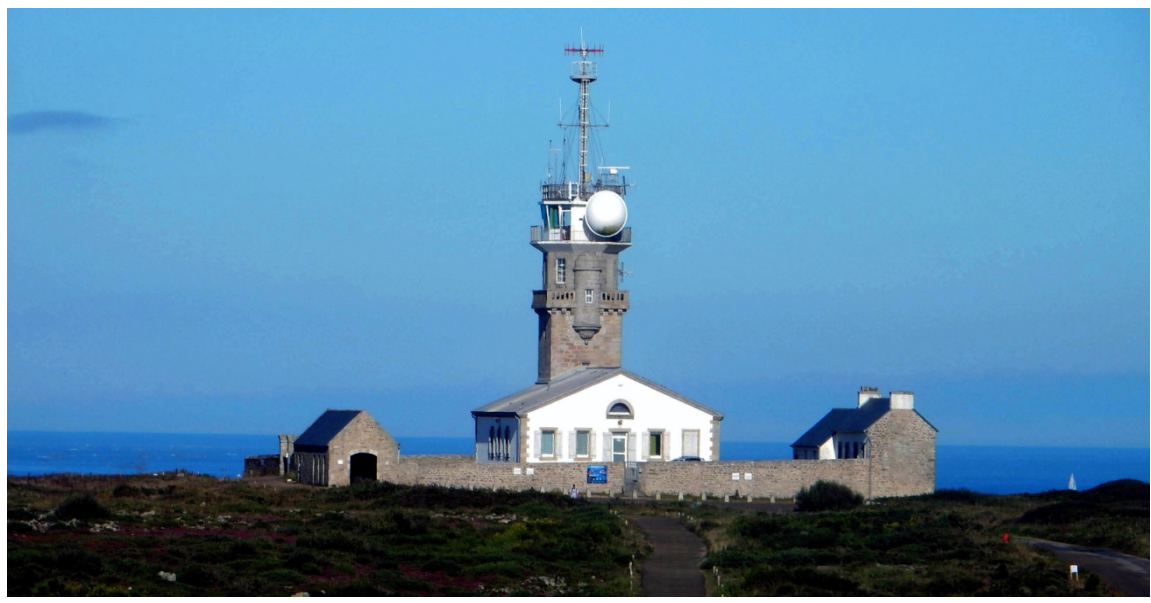

(a)

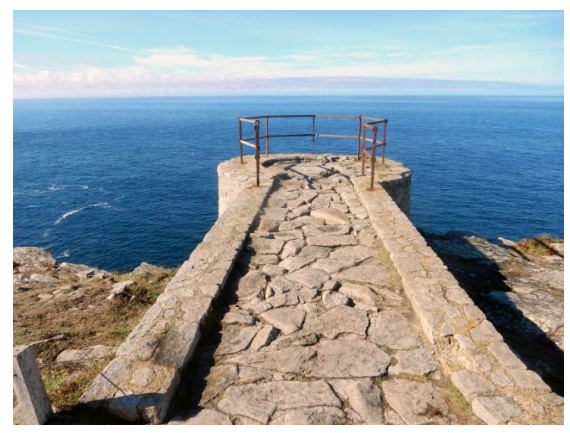

(b)

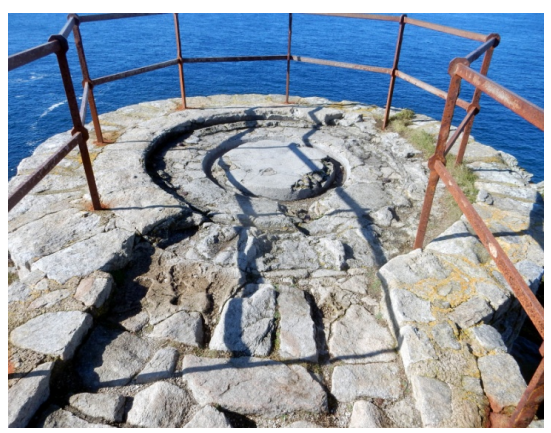

(c)

Figure 3. (a) Semaphore (1); (b) Details of the base of the 1875 headlight; (c) Gun emplacement.

The semaphore $\left(48^{\circ} 2^{\prime} 11.31^{\prime \prime} \mathrm{N}, 4^{\circ} 44^{\prime} 16.38^{\prime \prime} \mathrm{W}\right.$, height $\left.69.45 \mathrm{~m}\right)(1)$. Its $44 \times 44$ $\mathrm{m}$ stone enclosure, the quadrangular tower and the building leaning against, destroyed by the garrison, were well reconstructed. The Flak emplacement at the 
top of the tower disappeared replaced by a modern white structure equipped with antennas. Recent constructions replaced ancient constructions at the sides of the stone enclosure. The semaphore is still operated by the Marine Nationale.

The base of a metal sheet 1875 headlight $\left(48^{\circ} 2^{\prime} 20.65^{\prime \prime} \mathrm{N}, 4^{\circ} 44^{\prime} 9.82^{\prime \prime} \mathrm{W}\right.$, h. 30.63 m) (3) $200 \mathrm{~m}$ west from the semaphore, used as $37 \mathrm{~mm}$ Flak gun emplacement (Danzé et al., 2017). Formed by two converging stone walls and a circular emplacement filled with stones. Its reconstructed structure was in good preservation state.

The hotels (6), near the semaphore used as garrison lodgements, the antenna and buildings of the French Marine Nationale transmission station north of the semaphore, two French $95 \mathrm{~mm} 1888$ Lahitolle guns and their supports installed west of the semaphore, the chapel near the Notre Dame des Naufragés monument (2), the shacks $(7-8,10-12)$, the water reservoir/pool (9), the heap of debris (13), the FuMO 214 Würzburg-See-Riese and its support, installed west to the semaphore, on a round stone platform, probably built by the Marine Nationale (Blanchart, 2021), dynamited by the garrison (Danzé et al., 2017) and the square, brick shelter of the Freya SeeTakt G $41 \mathrm{~g} 310$ FuMO 2 Calais B, dynamited by the garrison (Danzé et al., 2017), disappeared because of after war interventions devoted to restoring the Pointe wild nature.

\subsection{Qu 500}

The Qu 500 identified components (Figures 4-9) were the following.

An L 479 Anton ( $48^{\circ} 2^{\prime} 18.24^{\prime \prime} \mathrm{N}, 4^{\circ} 43^{\prime} 5.86^{\prime \prime} \mathrm{W}$, h. $69.16 \mathrm{~m}$ ) (1) (Appendix Figure A1 and Figure A2) for night-fighter control, similar to those of $L A 318$

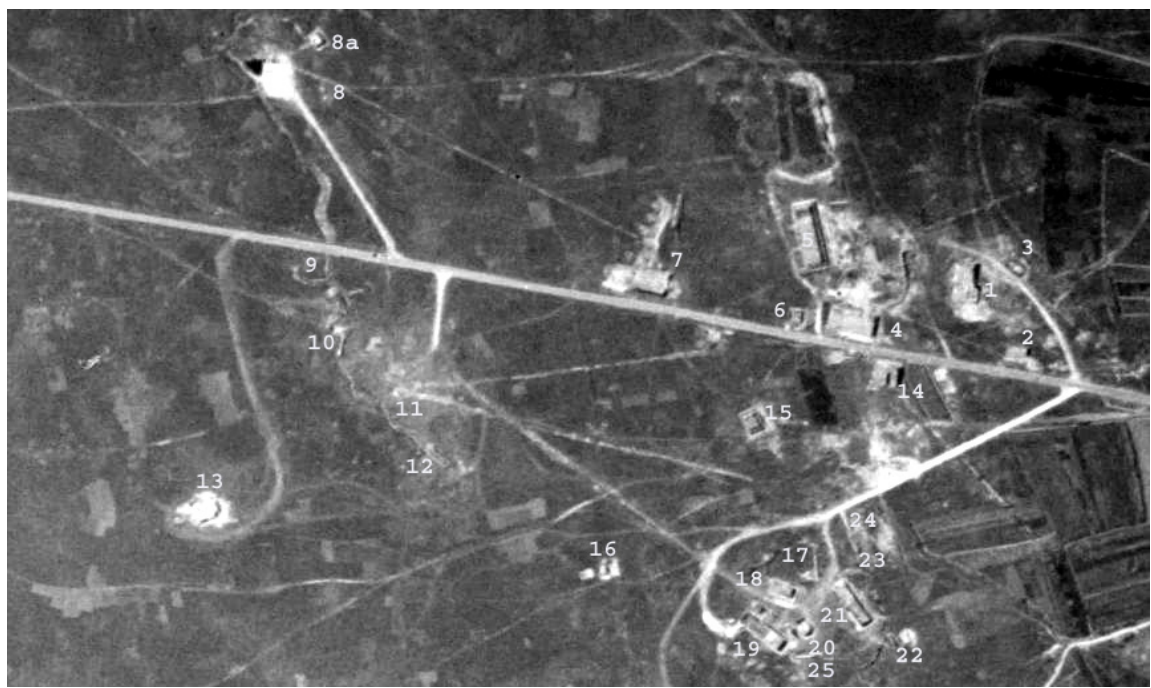

Figure 4. Qu 500-1 L 479 Anton; 2 L 486, 3 Vf 61a; 4 - 5 shack ditches; 6 square bunker; 7 shacks; 8 V 229; 8a square excavation; 9 possible bunker; 10 Flak emplacement and $R$ 655; $11 V$ 229; 12 R 622; 13 excavation; 14 shack ditch; 15 infirmary shack ditch; 16 possible Flak emplacement; 17 L 410 A; 18-19 shack ditches; 20 Freya emplacement; 21 shack ditch; 22 L 409 A; 23 RS 58c, 24 open cistern; 25 buried bunker. [Geoportail] Image C0319-0061_1952_F0319-0819_0074, nº74, 1/26347, Argentique, 24/05/1952. 


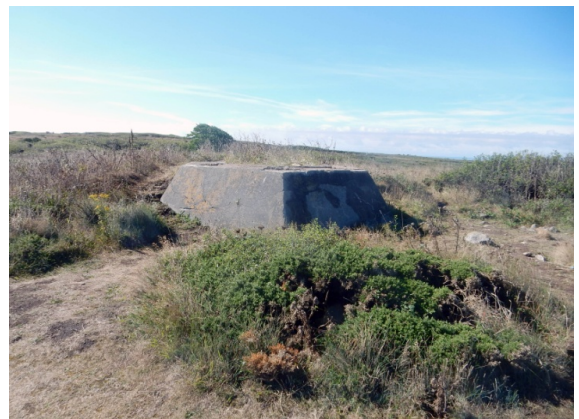

(a)

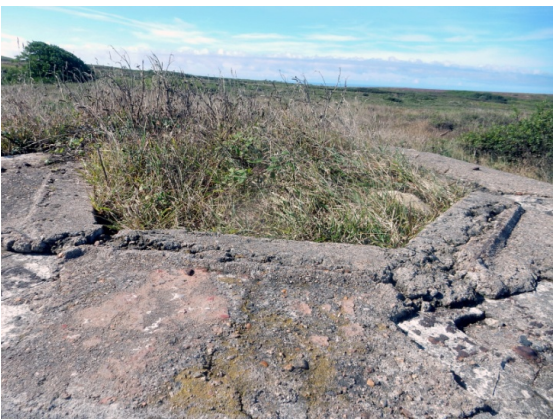

(b)

Figure 5. V 229 (8): (a) General view; (b) Upper side and interior, on the right fixation point for Würzburg-Riese.

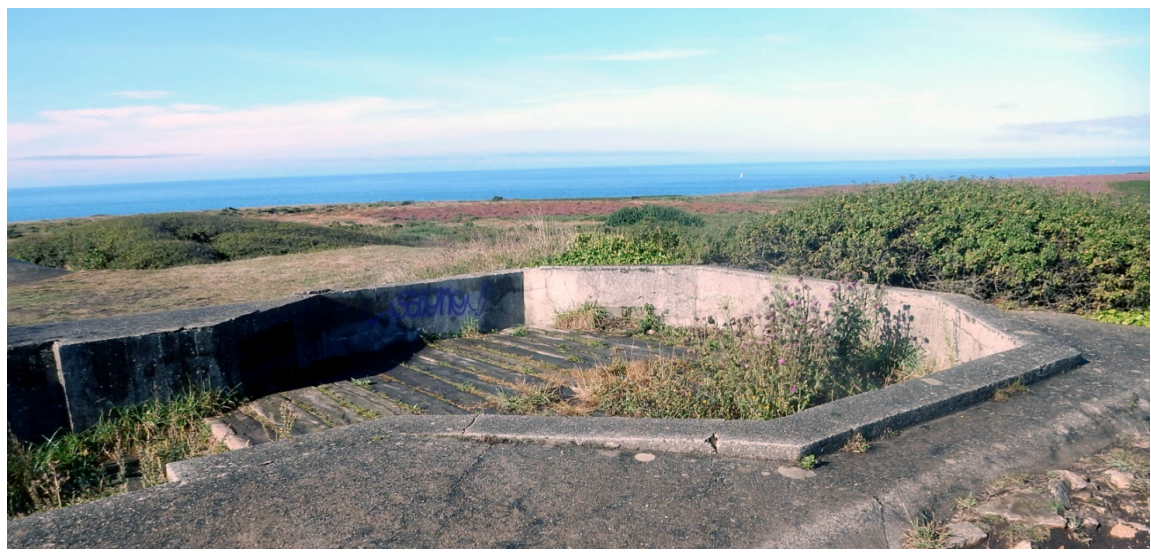

(a)

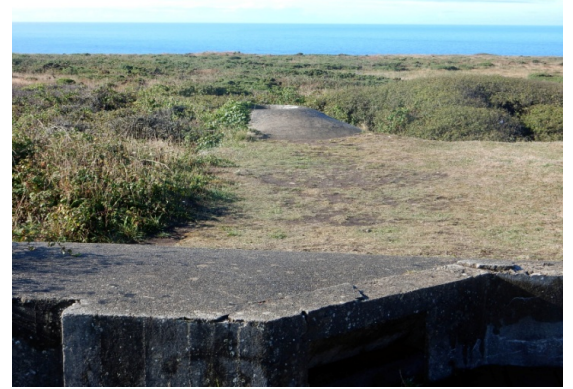

(b)

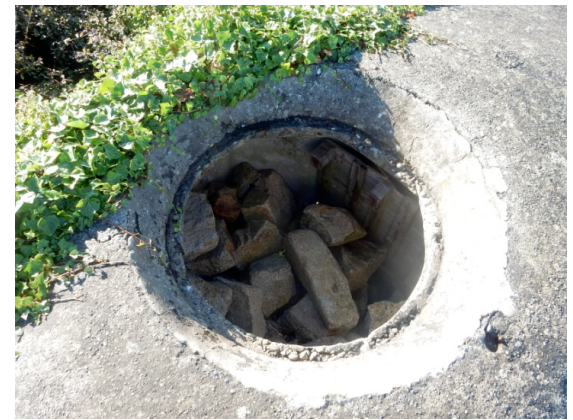

(c)

Figure 6. (a) Octagonal Flak emplacement (10); (b) $R$ 655, observation post; (c) Observation post interior.

Frosch at Cap Fréhel (Tomezzoli \& Moser, 2021), of Re 510 Pinguin at SaintPabu-Le Bous (Tomezzoli \& Colliou, 2017, 2018) and of Saint-Jacques de la Lande (Dupont et al., 2007). The terrain and vegetation coverage precluded access to the entrances and the interior. The emerging portion appeared in good preservation state.

A $9 \times 9 \mathrm{~m}$ square bunker $\left(48^{\circ} 2^{\prime} 16.55^{\prime \prime} \mathrm{N}, 4^{\circ} 43^{\prime} 54.24^{\prime \prime} \mathrm{W}\right.$, h. $66.7 \mathrm{~m}$ ) (6) buried in the terrain, for energy production (Danzé et al., 2017). The concrete coverage, emerging from the terrain, was in good preservation state. 


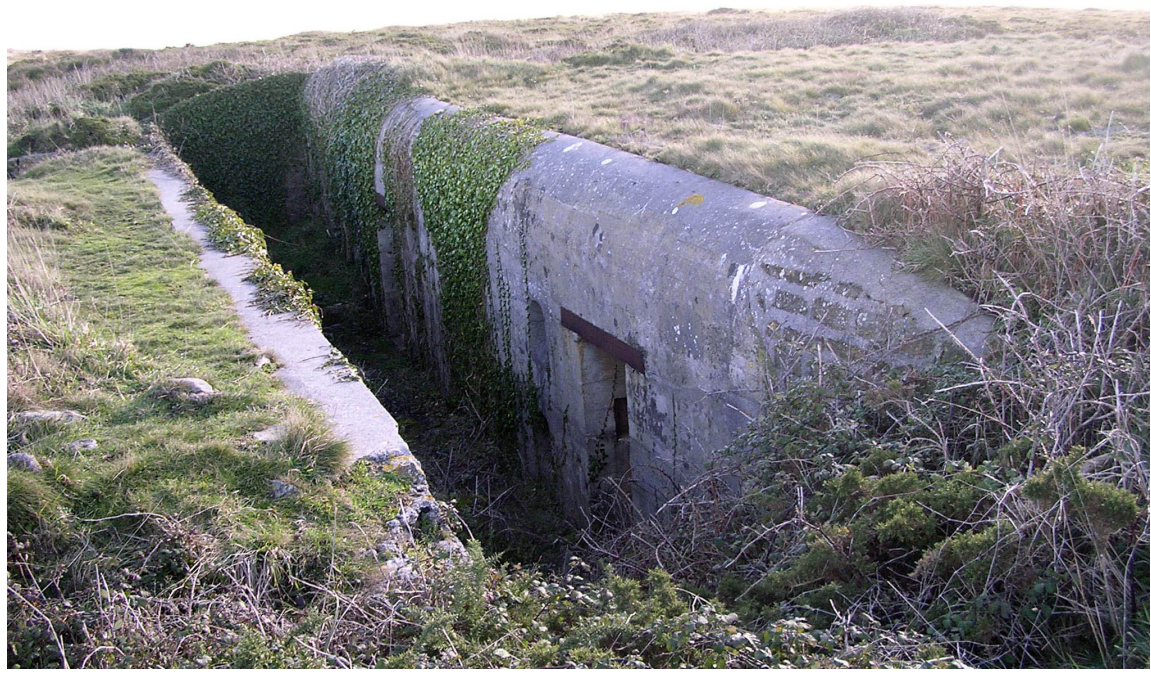

(a)

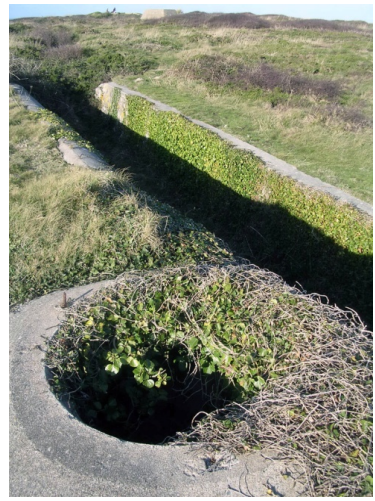

(b)

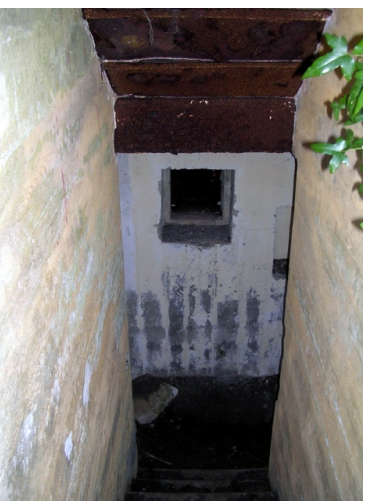

(c)

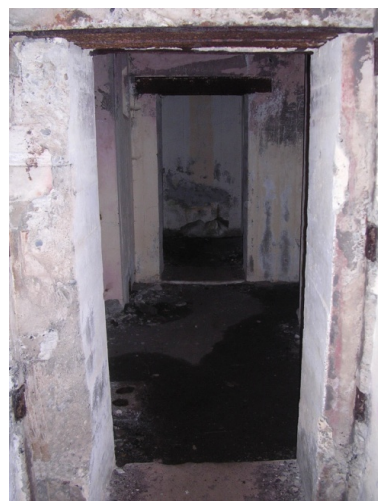

(d)

Figure 7. R 622 (12): (a) Façade, access trench and personnel entrances; (b) Access trench and external observation post; (c) Entrance ladder with close combat room louver; (d) Gaslock.

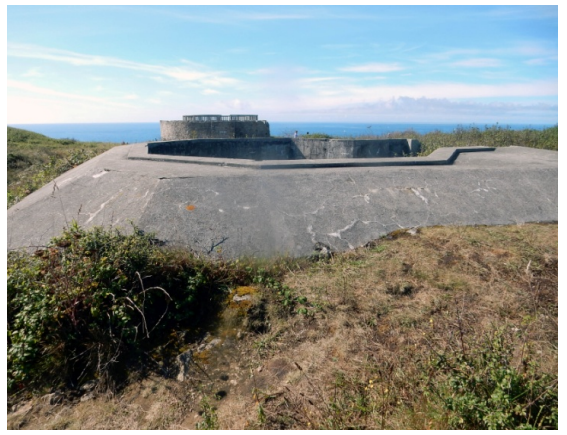

(a)

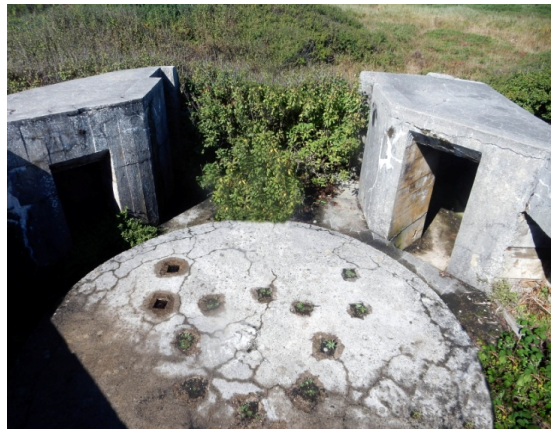

(b)

Figure 8. L 410 A (17): (a) Gun emplacement, on the background Freya emplacement; (b) Concrete gun support with intrusions.

A $16 \times 13 \mathrm{~m}$ ditch $\left(48^{\circ} 2^{\prime} 14.06^{\prime \prime} \mathrm{N}, 4^{\circ} 43^{\prime} 10.31^{\prime \prime} \mathrm{W}\right.$, h. $\left.67.15 \mathrm{~m}\right)$ (15) now part of the Maison de la Pointe du Raz et du Cap Sizun, hosting the rests of an infirmary shack used nowadays as exhibition centre. Its east side was provided with two 


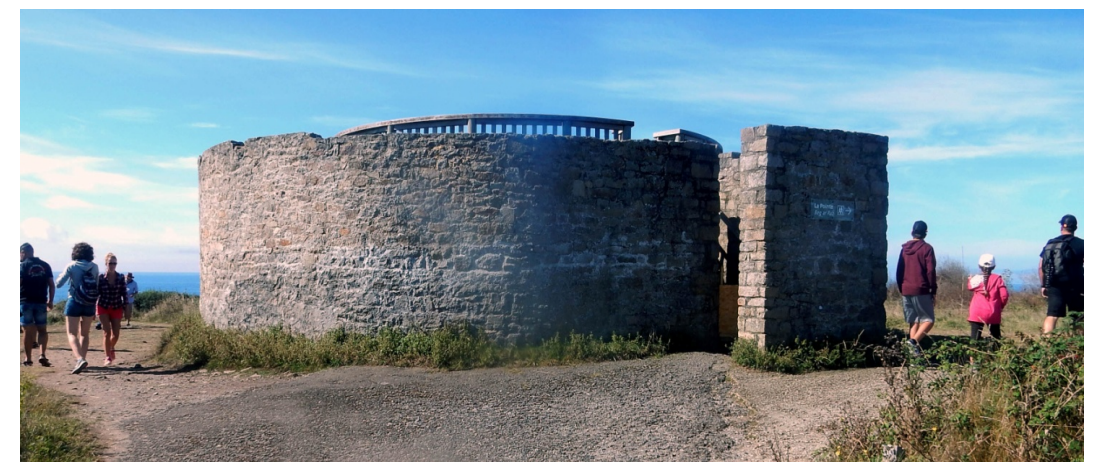

(a)

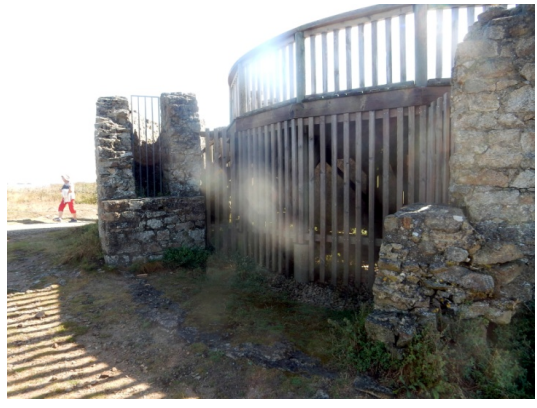

(b)

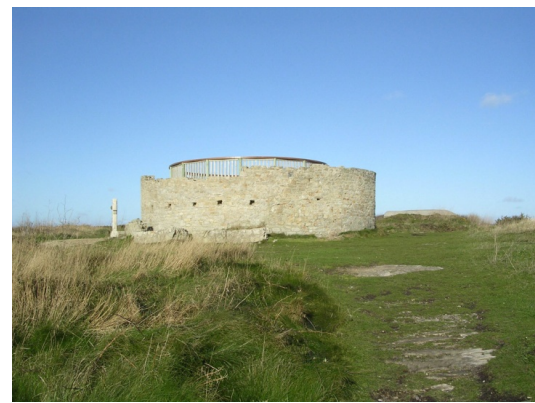

(c)

Figure 9. Cylindrical stone construction (20): (a) Labyrinth personnel entrance; (b) Material entrance and double protection wall; (c) Loopholes and collapsed portions of the protection wall on the terrain.

access ladders. Its concrete structure was in good preservation state. The ditch entrance was closed so that the preservation state of the shack was not be ascertained.

A $V 229\left(48^{\circ} 2^{\prime} 22.15^{\prime \prime} \mathrm{N}, 4^{\circ} 43^{\prime} 26.61^{\prime \prime} \mathrm{W}\right.$, h. $\left.69.26 \mathrm{~m}\right)(8)$. The interior was invaded by vegetation. On the upper side were the traces of the Würzburg-Riese supporting elements. The concrete structure was in good preservation state.

A square $6 \times 6 \mathrm{~m}$ degraded excavation $\left(48^{\circ} 2^{\prime} 24.51^{\prime \prime} \mathrm{N}, 4^{\circ} 43^{\prime} 26.46^{\prime \prime} \mathrm{W}\right.$, h. 59.33 m) (8a), $0.5 \mathrm{~m}$ deep, $70 \mathrm{~m}$ north of the $V 229$, for a Flak gun.

An octagonal, $6 \mathrm{~m}$ in diam. Flak emplacement $\left(48^{\circ} 2^{\prime} 15.46^{\prime \prime} \mathrm{N}, 4^{\circ} 43^{\prime} 24.02^{\prime \prime} \mathrm{N}\right.$, h. $74.2 \mathrm{~m}$ ) (10), $0.5 \mathrm{~m}$ deep for a 2.0/3.7 cm Flak gun. Wooden boards covered the floor. The concrete structure was in good preservation state. It was leaning against an $R 655$ buried in the terrain, with external observation post filled with stones. Its emerging concrete structure was in good preservation state.

A $V 229\left(48^{\circ} 2^{\prime} 14.35^{\prime \prime} \mathrm{N}, 4^{\circ} 43^{\prime} 22^{\prime \prime} \mathrm{W}, \mathrm{h} .73 .83 \mathrm{~m}\right)(11)$. The internal floor was filled with stones. On the internal walls two recesses for shelves or equipments. On the upper side metallic fixation bolts and the traces of the corresponding Würzburg-Riese supporting elements. On the walls, pebbles of the EroVili (Tomezzoli \& Marzin, 2015) mixed with concrete. The concrete structure was in good preservation state.

An $R 622\left(48^{\circ} 2^{\prime} 12.76^{\prime \prime} \mathrm{N}, 4^{\circ} 43^{\prime} 20.76^{\prime \prime} \mathrm{W}\right.$, h. $\left.73.18 \mathrm{~m}\right)$ (12) (Appendix Figure A7) with observation post and access trench. The two entrances gave access to 
ladders and to the interior which preserved the original wall white painting and rusted ceilings. All the internal furniture disappeared. The concrete structure was in good preservation state.

A degraded excavation $\left(48^{\circ} 2^{\prime} 11.71^{\prime \prime} \mathrm{N}, 4^{\circ} 43^{\prime} 27.13^{\prime \prime} \mathrm{W}\right.$, h. $\left.66.35 \mathrm{~m}\right)$ (13) probably for one or more shacks, formed by a $15 \times 10 \mathrm{~m}$ portion joined to a $27 \times 12 \mathrm{~m}$ portion, about $2 \mathrm{~m}$ deep.

An $L 410$ A $\left(48^{\circ} 2^{\prime} 10.57^{\prime \prime} \mathrm{N}, 4^{\circ} 43^{\prime} 8.29^{\prime \prime} \mathrm{W}, \mathrm{h} .70 .27 \mathrm{~m}\right)$ (17) (Appendix Figure A3) (Tomezzoli \& Colliou, 2017) buried in the terrain, only the external octagonal Flak emplacement emerged. At the access, in the concrete, the vertical grooves for the wood closure, on the sidewalls, ammunition niches, at the centre a $3.5 \mathrm{~m}$ in diam. circular support for a 2.0/3.7 cm Flak gun. On the support the Ero Vili pebbles, around its centre a circular alignment of eight square intrusions and near the circumference four other rectangular disposed intrusions. On one external side the rests of a $30 \mathrm{~cm}$ in diam. chimney. The entrances buried in the terrain prevented the inspection of the interior. The Flak emplacement was in good preservation state.

A 6.20 in diam., $2.40 \mathrm{~m}$ high (Blanchard, 2021), cylindrical stone construction $\left(48^{\circ} 2^{\prime} 19.78^{\prime \prime} \mathrm{N}, 4^{\circ} 43^{\prime} 8.32^{\prime \prime} \mathrm{W}\right.$, h. $\left.69.03 \mathrm{~m}\right)(20)$ as a Middle Ages one, for Freya, similar to that of $L A 318$ (Tomezzoli \& Moser, 2021). It comprised a double external wall provided with personnel, labyrinth entrance and a material entrance. The Freya cabin and its antenna were inside and because no lodgement was foreseen, the personnel lodged in the nearby shacks. Recently restored, its structure was in good preservation state, although some portions of the external wall collapsed perhaps because of the explosion of an English bomb on $9^{\text {th }}$ July 1944 (Danzé et al., 2017).

An $L 409$ A $\left(48^{\circ} 2^{\prime} 9.27^{\prime \prime} \mathrm{N}, 4^{\circ} 43^{\prime} 5.14^{\prime \prime} \mathrm{W}\right.$, h. $\left.67.06 \mathrm{~m}\right)$ (22) (Appendix Figure A4) buried in the terrain, only the octagonal emplacement for a 2.0/3.7 cm Flak gun emerged. The dense vegetation prevented access to the personnel entrances for the interior inspection and to the gun emplacement. The visible portions were in good preservation state, notwithstanding a minor damage at the entrance of the emplacement letting visible Ero Vili pebbles mixed with the concrete.

An $R S 58 c\left(48^{\circ} 2^{\prime} 10.26^{\prime \prime} \mathrm{N}, 4^{\circ} 43^{\prime} 6.17^{\prime \prime} \mathrm{W}\right.$, h. 67.19) (23) at the south west corner of the modern parking, at $35 \mathrm{~m}$ from the $L 409 A$ (22) connected to it by an access trench. The portion emerging from the vegetation was in good preservation state.

A $2 \times 1 \mathrm{~m}$ open cistern $\left(48^{\circ} 2^{\prime} 19.78^{\prime \prime} \mathrm{N}, 4^{\circ} 43^{\prime} 54.24^{\prime \prime} \mathrm{W}, \mathrm{h} .69 .32 \mathrm{~m}\right)(24)$ at the south west corner of the parking, at $50 \mathrm{~m}$ from the $L 409 A(22)$ and at $15 \mathrm{~m}$ from the $R S 58 \mathrm{C}$ (23), similar to those observed at $\mathrm{Be}-2$ at Mont Saint Michel de Braspart (Tomezzoli \& Dupont, 2011) and at La 318 (Tomezzoli \& Moser, 2021). The dense vegetation prevented to reach it for determining its preservation state.

A $7 \times 9$ bunker $\left(48^{\circ} 2^{\prime} 8.49^{\prime \prime} \mathrm{N}, 4^{\circ} 43^{\prime} 8.15^{\prime \prime} \mathrm{W}\right.$, h. 67.93$)$ (25) buried in the terrain. The emerging coverage was in good preservation state. The entrances buried in the terrain prevented the inspection of the interior. 
An $L 486\left(48^{\circ} 2^{\prime} 17.62^{\prime \prime} \mathrm{N}, 4^{\circ} 43^{\prime} 4.43^{\prime \prime} \mathrm{W}\right.$, h. 69.46) (2) was completely buried in the terrain, a $V f 61 a\left(48^{\circ} 2^{\prime} 17.79^{\prime \prime} \mathrm{N}, 4^{\circ} 43^{\prime} 1.92^{\prime \prime} \mathrm{W}, \mathrm{h} .70 .75\right)(3)$ for a mortar was still visible, the shack ditches $(4-5,7,14,18$ - 19,21) disappeared; a possible bunker (9) was buried in the terrain; a possible Flak emplacement (16) was not identified.

\subsection{Qu 13}

The $Q u 13$ identified components (Figures 10-16) were the following.

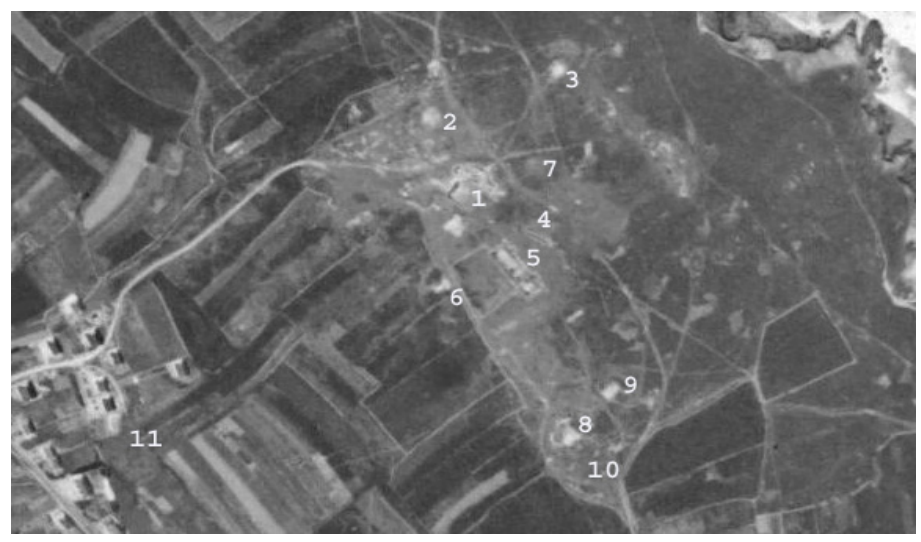

Figure 10. Qu 13-1 L 485(1); 2 R 667; 3 Vf 2a; 4 R 622; 5 kitchen and canteen ditch; 6 Vf $1 b$; 7 possible bunker; 8 Vf $1 b$ "abri tolle metro"; 9 Vf 2a; 10 RS 58c, 11 Lescoff. [Geoportail] Image C0319-0041_1961_F0319-0519P_0055, n55, 1/25710, Argentique, 21/06/1961.

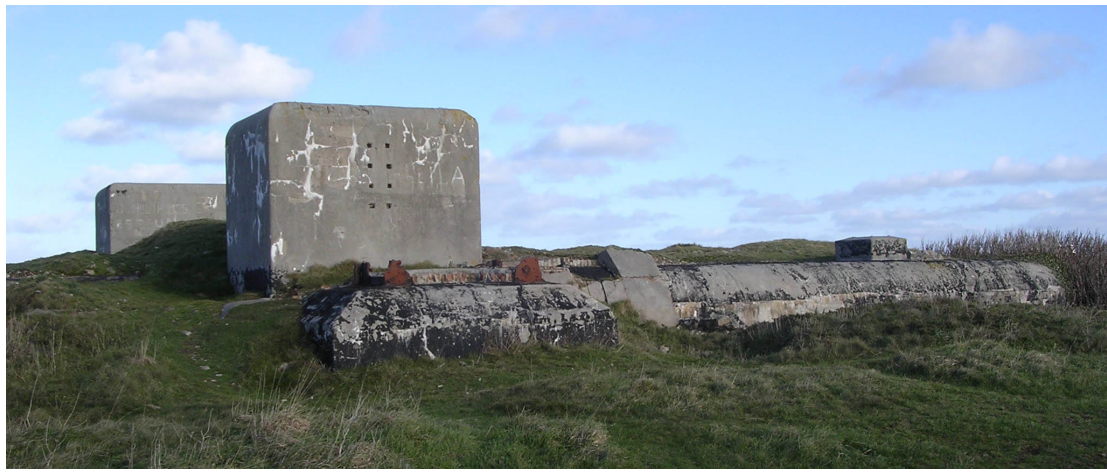

(a)

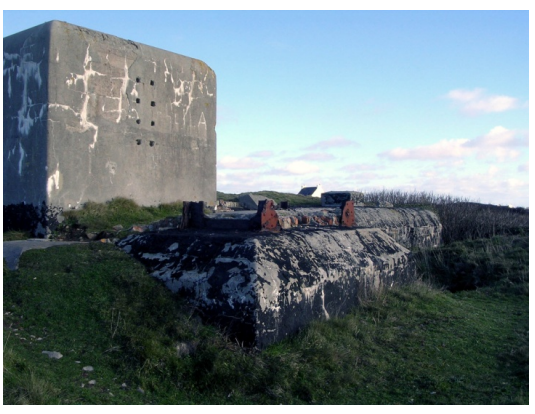

(b)

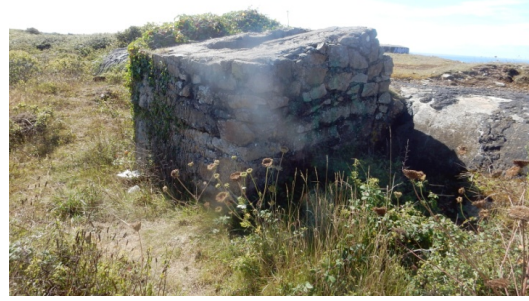

(c)

Figure 11. L 485 (I) (1): (a) General view, on the left the pylons and the west antenna support, on the right the chimney; (b) West antenna support; (c) Emergency exit pit. 


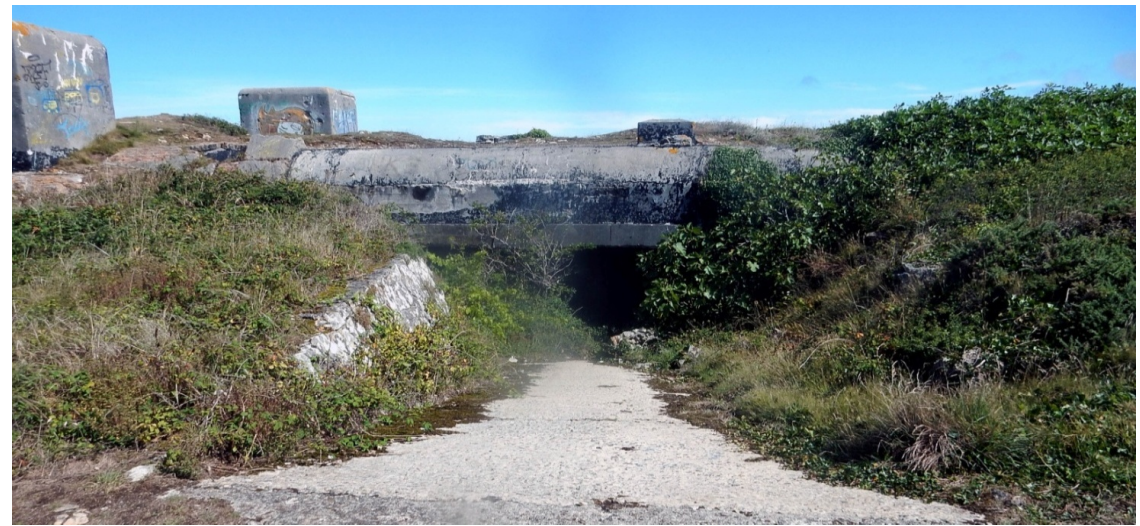

(a)

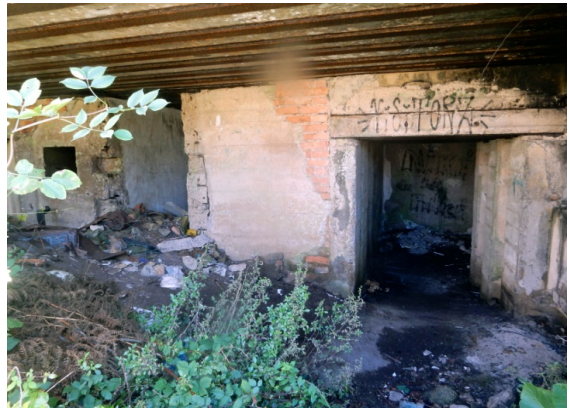

(b)

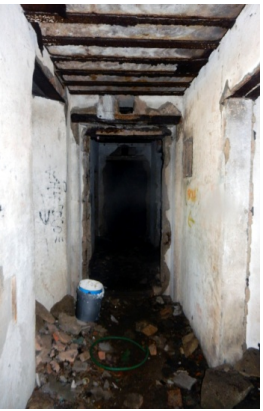

(c)

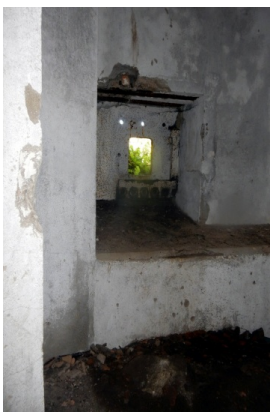

(d)

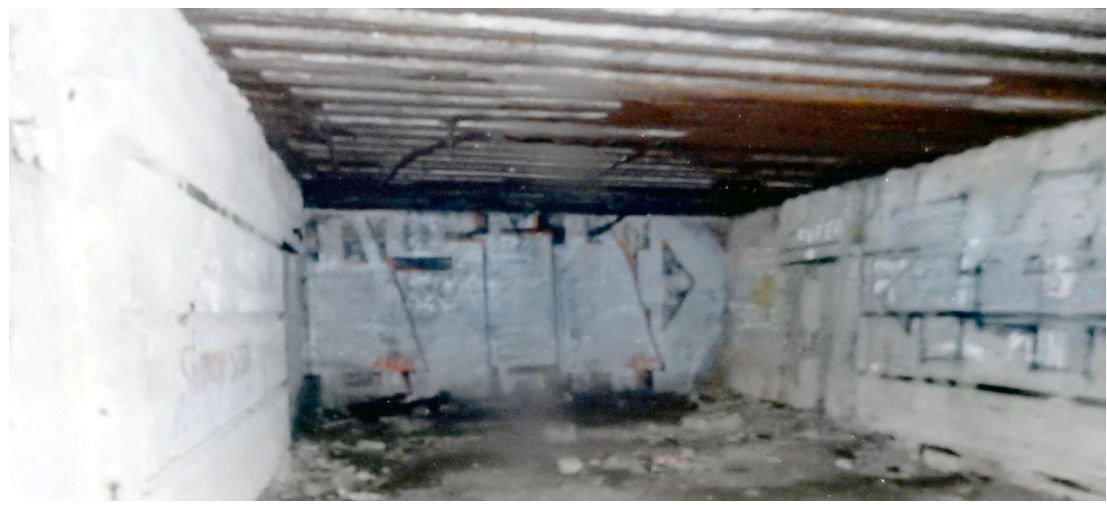

(e)

Figure 12. L 485 (1) (1): (a) Inclined concrete ramp; (b) Entrances, on the left loophole of the close combat room; (c) Gaslock; (d) Close combat room with loophole metallic plate; (e) Compensator room and workshop, left and right entrances to the antenna rooms, rusted ceiling.

An $L 485(1)\left(48^{\circ} 2^{\prime} 26.01^{\prime \prime} \mathrm{N}, 4^{\circ} 42^{\prime} 40.16^{\prime \prime} \mathrm{W}\right.$, h. $\left.76.47 \mathrm{~m}\right)$ (1) (Appendix Figure A5 and Figure A6) for Mammut radar, oriented north-west south-east, partly buried in the terrain. Mainly built in concrete, some portions were in bricks or stones. Rests of a bitumen layer on the coverage, indicated that it was provided with an insulation system. Two $3 \times 2 \mathrm{~m}$ rectangular pylons for the descent of antenna cables, disfigured by modern graffiti, but in good preservation state and a $1 \times 1 \mathrm{~m}$ chimney protruded from the coverage. The antenna supports between the pylons were buried in the terrain. An east and west $3 \times 2 \mathrm{~m}$ antenna support, 


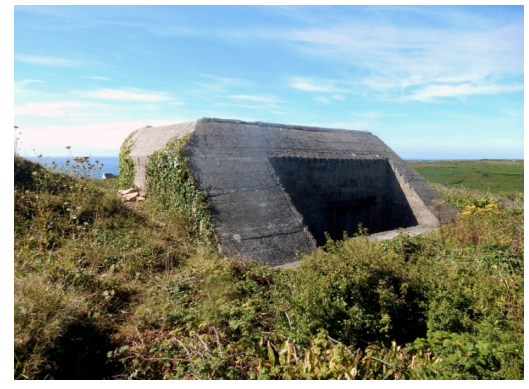

(a)

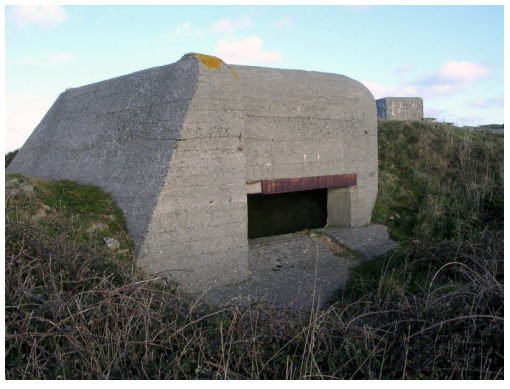

(b)

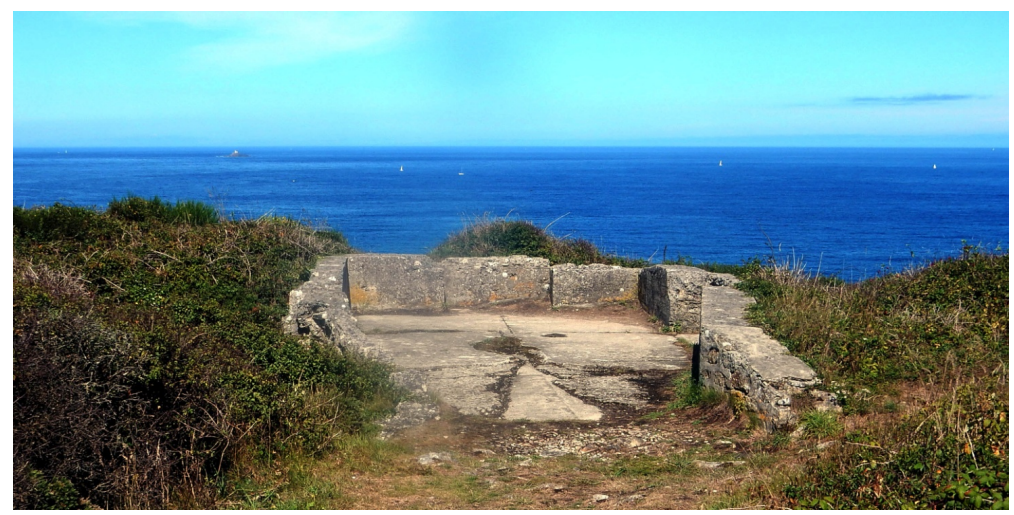

(c)

Figure 13. (a) $R 667$ (2) inclined rear side; (b) $R 667$ (2) front side, combat room opening and protective wing; (c) Vf $2 a(3)$, coverage with protective wall.

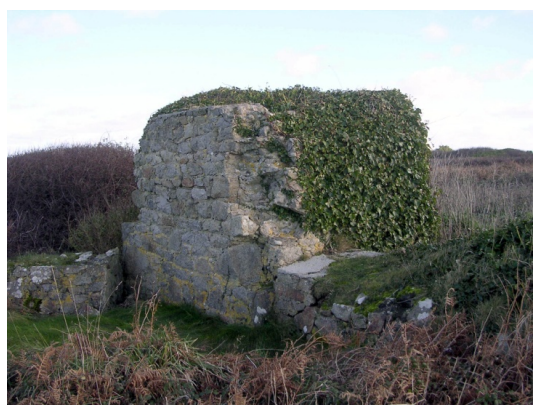

(a)

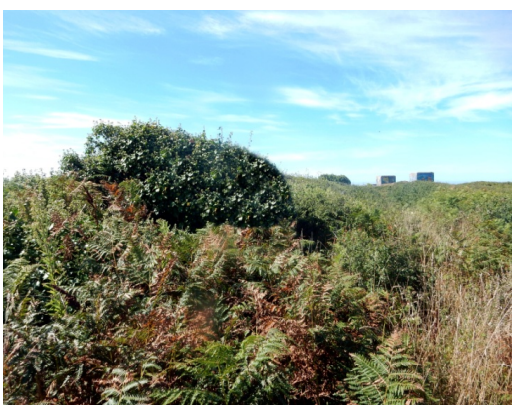

(b)

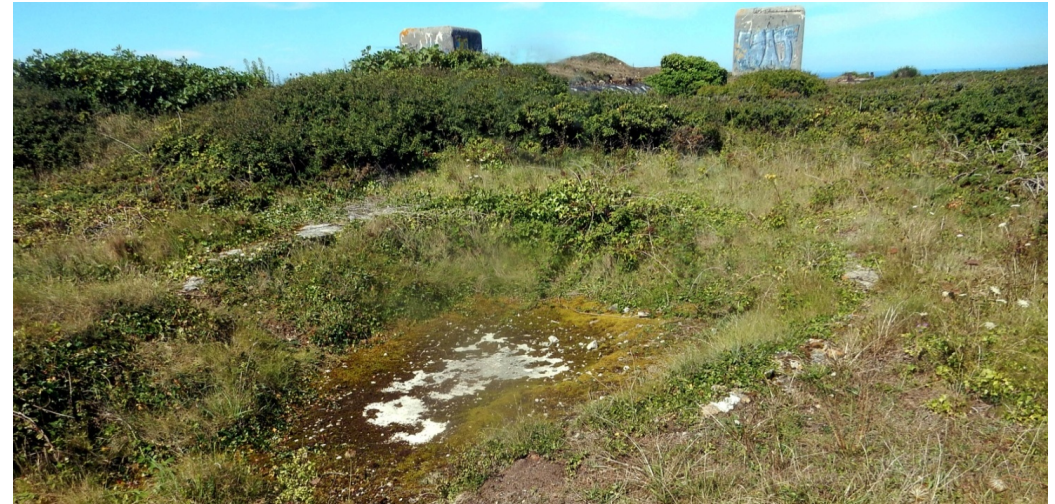

(c)

Figure 14. (a) Second $3 \times 3$ m constructions; (b) Third $3 \times 3$ m construction (c) Possible Flak emplacement. 


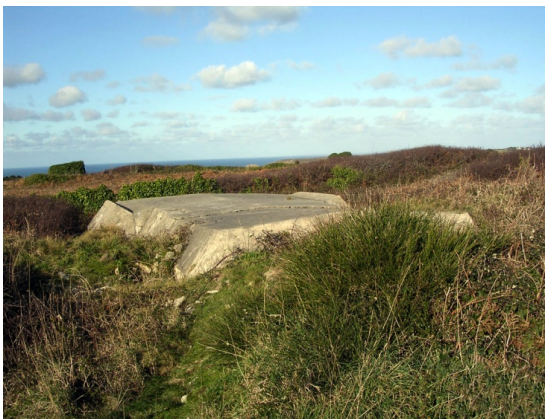

(a)

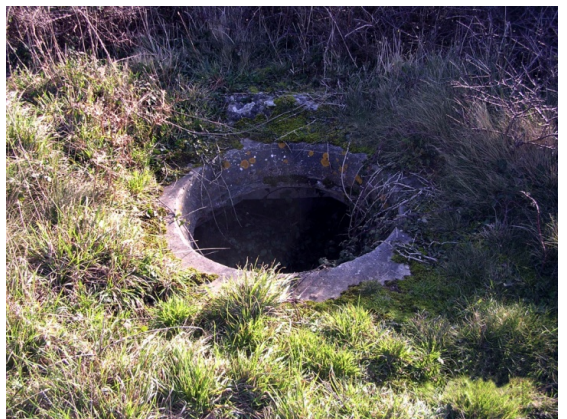

(b)

Figure 15. (a) $V f 1 b$, in the background second and third $3 \times 3$ m constructions; (b) $R S$ $58 c$ near $V f 1 b$, circular opening of the combat room.

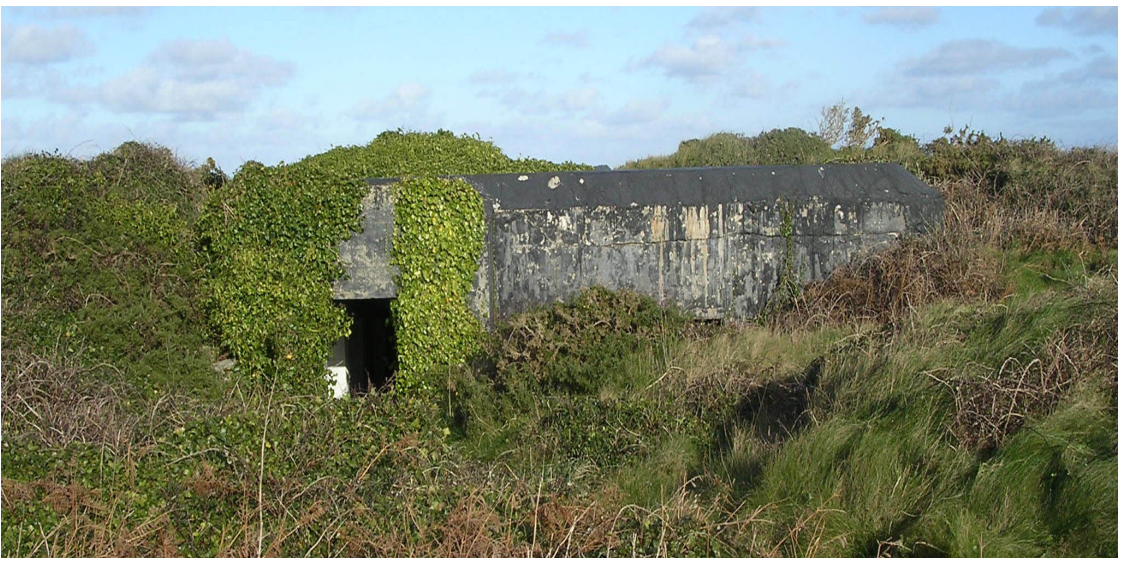

(a)

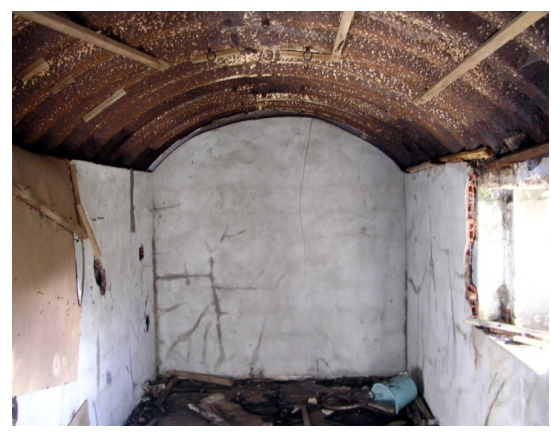

(b)

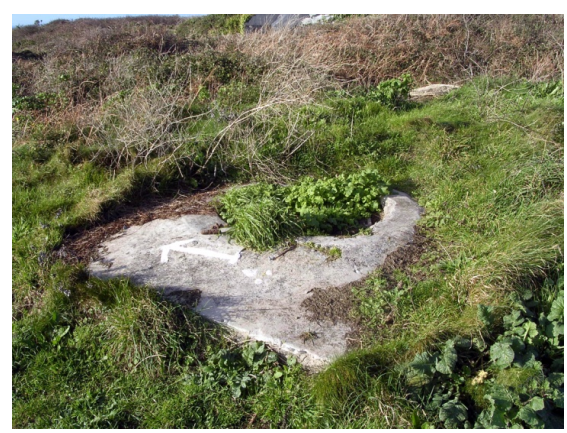

(c)

Figure 16. (a) Vf $1 b$ "abri tôle de metro" general view (11); (b) Internal room with window and rusted curved ceiling; (c) RS 58c (10).

at the exterior of the pylons, emerged from the terrain, letting visible bricks, the bitumen layer, four metallic antenna portions fixed to a rectangular metallic fixing frame embedded in the concrete. On the north side, a $2 \times 1 \mathrm{~m}$ open cistern covered by vegetation and on the east side a $2 \times 2$ stone pit of an emergency exit. On the west side, a concrete inclined ramp led to the entrances protected by the loophole of a close combat room. The internal rooms preserved the original white wall painting, somewhere disfigured by modern graffiti, and severely rusted ceilings. All the internal furniture disappeared and the floors were clut- 
tered by terrain and stones not collapsed from the walls. The close combat room preserved the metallic plate of its loophole. The workshop and compensator rooms formed a unique room. On its floor were traces of the compensator support. All the metallic doors, cables, technical instrumentations and furniture disappeared. After war images show that the Mammut antenna disappeared before 1948 , after its fall to the ground.

A $R 667\left(48^{\circ} 2^{\prime} 25.31^{\prime \prime N}, 4^{\circ} 40.35^{\prime \prime W}\right.$, h. $\left.75.41 \mathrm{~m}\right)$ (2) (Appendix Figure A8) for a $5 \mathrm{~cm} \mathrm{KwK} \mathrm{(Kampfwagenkanone)} \mathrm{gun.} \mathrm{The} \mathrm{entrance,} \mathrm{in} \mathrm{the} \mathrm{inclined} \mathrm{rear} \mathrm{side,}$ introduced in the combat room which preserved walls disfigured by contemporary graffiti, an ammunition niche on the floor and a rusted ceiling. All the internal furniture disappeared and on the floor, the gun emplacement was covered by stones. The front side hosted the combat room front aperture and a protective wing. The concrete structure was in good preservation state, letting visible EroVili pebbles mixed with concrete and formwork element traces.

A Vf $2 a\left(48^{\circ} 2^{\prime} 27.67^{\prime \prime N}, 4^{\circ} 42^{\prime} 41.85^{\prime \prime} \mathrm{W}, \mathrm{h} .71 .96 \mathrm{~m}\right)$ (3) for a projector (Danzé et al., 2017). The coverage, emerging from the terrain, was limited by a protection wall formed by stones and concrete. On the west side, two pits were covered by vegetation. Terrain and vegetation covering the access trench and the entrance prevented the inspection of the interior. The coverage and the protective wall were in good preservation state.

An $R 622\left(48^{\circ} 2^{\prime} 27.26^{\prime \prime} \mathrm{N}, 4^{\circ} 42^{\prime} 37.02^{\prime \prime} \mathrm{W}\right.$, h. $77.42 \mathrm{~m}$ ) (4) (Appendix Figure A7) for two groups of ten soldiers (Rudi, 1988) $32 \mathrm{~m}$ north-east from the $L 485(1)$. Dense vegetation invaded the coverage, the access trench and obstructed the entrances; therefore its preservation state was not ascertained.

A first $3 \times 3 \mathrm{~m}$ construction $\left(48^{\circ} 2^{\prime} 26.43^{\prime \prime} \mathrm{N}, 4^{\circ} 42^{\prime} 37.32^{\prime \prime} \mathrm{W}, \mathrm{h} .77 .59 \mathrm{~m}\right)$ provided with access trench. Completely covered by vegetation, its purpose and preservation state was not ascertained.

A second $3 \times 3 \mathrm{~m}$ construction $\left(48^{\circ} 2^{\prime} 26.71^{\prime \prime} \mathrm{N}, 4^{\circ} 42^{\prime} 36.5^{\prime \prime} \mathrm{W}, \mathrm{h} .77 .82 \mathrm{~m}\right)$ partially covered by vegetation. It was one of the two stone emerging structures of a kitchen and canteen ditch (5). The visible stone portion was in good preservation state.

A third $3 \times 3 \mathrm{~m}$ construction $\left(48^{\circ} 2^{\prime} 27.32^{\prime \prime} \mathrm{N}, 4^{\circ} 42^{\prime} 35.38^{\prime \prime} \mathrm{W}, \mathrm{h} .78 .01 \mathrm{~m}\right)$ covered by vegetation. It was one of the two emerging structures of a kitchen and canteen ditch (5). Completely covered by vegetation, its preservation state was not ascertained.

A $40 \times 10 \mathrm{~m}$ kitchen and canteen ditch $\left(48^{\circ} 2^{\prime} 26.86^{\prime \prime} \mathrm{N}, 4^{\circ} 42^{\prime} 35.78^{\prime \prime} \mathrm{W}\right.$, h. 78.12 m) (5) completely filled by terrain and vegetation. It was provided with an access ladder on each short side. Only its rectangular outline was discernible on the terrain.

A $V f 1 b\left(48^{\circ} 2^{\prime} 24.25^{\prime \prime} \mathrm{N}, 4^{\circ} 42^{\prime} 35.3^{\prime \prime} \mathrm{W}\right.$, h. $\left.78.48 \mathrm{~m}\right)(6)$ for servants of two disappeared nearby Flak emplacements, buried in the terrain, only its rectangular coverage emerged. The entrance buried in the terrain prevented the inspection of the interior. The coverage was in good preservation state, notwithstanding a 3 $\mathrm{cm}$ wide fissure crossing its width, caused by an architectural failure. 
A $R S 58 c\left(48^{\circ} 2^{\prime} 25.18^{\prime \prime} \mathrm{N}, 4^{\circ} 42^{\prime} 35.23^{\prime \prime} \mathrm{W}, \mathrm{h} .78 .62 \mathrm{~m}\right) 5 \mathrm{~m}$ south to the $V f 1 b(6)$ for the $Q 13$ south defence. Covered by terrain and vegetation, only the well preserved circular opening of the combat room was visible.

A possible, $0.5 \mathrm{~m}$ deep Flak emplacement $\left(48^{\circ} 2^{\prime} 26.57^{\prime \prime} \mathrm{N}, 4^{\circ} 42^{\prime} 38.1^{\prime \prime} \mathrm{W}\right.$, h. 78.29 m) $12 \mathrm{~m}$ south-east from the $L 485(1)$. Covered by moss and vegetation, appeared in a degraded preservation state.

A bunker $\left(48^{\circ} 2^{\prime} 25.74^{\prime \prime} \mathrm{N}, 4^{\circ} 42^{\prime} 31.84^{\prime \prime} \mathrm{W}, \mathrm{h} .79 .35 \mathrm{~m}\right)$ (7) $25 \mathrm{~m}$ north from the $L$ 485(1) provided with access trench. Completely covered by terrain and vegetation, its type and preservation state was not ascertained.

A $R S 58 c\left(48^{\circ} 2^{\prime} 27.46^{\prime \prime} \mathrm{N}, 4^{\circ} 42^{\prime} 39.41^{\prime \prime} \mathrm{W}, \mathrm{h} .75 .69 \mathrm{~m}\right) 10 \mathrm{~m}$ west from said bunker, for the $Q 13$ north and west defence. The vegetation obstructed its access trench so that its preservation state was not ascertained.

A Vf $1 b\left(48^{\circ} 2 ' 27.86^{\prime \prime} \mathrm{N}, 4^{\circ} 42^{\prime} 30.78^{\prime \prime} \mathrm{W}\right.$, h. $\left.79.13 \mathrm{~m}\right)$ (8) for personnel lodgement, partially covered by vegetation. Rests of a bitumen layer on the coverage, indicated that it was provided with an insulation system. An access trench led to one of the entrances and the internal room was provided with a window, preserving the original white wall painting and a curved rusted ceiling hence the name underground sheet shelter ("abri tôle de metro"). All the internal furniture disappeared. Its structure was in good preservation state.

A Vf $2 a\left(48^{\circ} 2^{\prime} 28.59^{\prime \prime} \mathrm{N}, 4^{\circ} 42^{\prime} 32.2^{\prime \prime} \mathrm{W}\right.$, h. $\left.79.65 \mathrm{~m}\right)$ (9) for personnel lodgment, buried in the terrain, only its rectangular coverage, in good preservation state, emerged. The vegetation covering the access trench and the entrance prevented the inspection of the interior.

A $R S 58 c\left(48^{\circ} 2^{\prime} 27.91^{\prime \prime} \mathrm{N}, 4^{\circ} 42^{\prime} 29.72^{\prime \prime} \mathrm{W}\right.$, h. $\left.79.34 \mathrm{~m}\right)(10) 10 \mathrm{~m}$ south-east from the $V f 1 b$, for the $Q 13$ east defence. Partially covered by vegetation, it appeared in good preservation state.

\section{Discussion}

The Pointe radar stations repeat the same dual organisation of the radar station $L A 318$ (Tomezzoli \& Moser, 2021) and RE 510 (Tomezzoli \& Colliou, 2017) consisting in separated radar stations operated respectively by the Kriegsmarine and the Luftwaffe. They repeat also the same architecture of $\operatorname{La} 318, \operatorname{Re} 510$, the radar station Mandrill at Monterfil (Dupont et al., 2007) and the radar station Made at Les Mées (Tomezzoli \& Pottier, 2015) consisting of two Freya and two Würzburg-Riese. These radars were necessary for assuring continue surveillance also in case of maintenance or malfunctioning of one of them. Freya was an early warning phased array radar detecting aircrafts up to $200 \mathrm{~km}$ but unable to determine their altitude. Würzburg-Riese, often coupled to an IFF (Identification Friend Foe) device, was a near field warning radar detecting aircrafts up to 70 $\mathrm{km}$, their azimuth and their altitude. Mammut was a phased array, early warning radar able to detect aircrafts up to $300 \mathrm{~km}$ in two directions perpendicular to its rectangular antenna, but blind in a range of $60^{\circ}$ on the antenna sides, designed to strengthen the surveillance capabilities of the radar stations. The reasons for 
which the $L 485$ (1) was selected for the Mammut instead of an $L 485(2)$ as at $L a$ 318 are unknown. Therefore, incoming aircrafts were first intercepted by the Mammut, after by the Freya and at the end by the Würzburg-Riese which, in case of foe aircrafts, provided data for directing the fire of the Flak emplacements. Indicated as unusable on a 1944 map made by an anonymous French informant probably working at the Pointe (Danzé et al., 2017), the Mammut was of limited or no surveillance effectiveness.

The eight shack ditches at the Pointe, also of considerable dimensions, offered more personnel safety, with respect to the six at the Stp at Menez Hom (Tomezzoli, 2017), the only one at $L A 318$ and no one at RE 500. All the shacks disappeared before 1948. Probably they were disassembled and rebuilt elsewhere as lodgements for the homeless French population (Tomezzoli, 2019).

The garrison was rather numerous. In 1944, at $Q u 300$ and $Q 500$ there were 130 soldiers and 3 officers from Austria and Germany and at Qu 1370 Luftwaffe and 20 Heer soldiers, between which 7 were from Poland (Danzé et al., 2017).

\section{Conclusion}

Different after-war interventions on the Pointe have been conducted in order to eliminate hotels, parking, and civilian constructions, and to restore its wild nature so as to elevate it at the rank of Grand Site de France. This is certainly a commendable effort, but up to now no effort at all has been made for documenting and preserving its involved military patrimony.

\section{Acknowledgements}

The author is grateful to Mr. Fleuridas P. for his permission to insert in the Appendices the plans of the $L 479$ Anton, $L 410 A, L 409 A, L 485, R 622$ and $R 667$, to Mr. Blanchard Y. for his explanations and to Mr. Floch A. for his permission of acquiring information concerning the Pointe during the WWII from his book.

\section{Conflicts of Interest}

The author declares no conflicts of interest regarding the publication of this paper.

\section{References}

Blanchard, Y., \& van Genderen, P. (2014). A German Radar Chain facing the British Home Chain during the WWII. 2014 11th European Radar Conference, Rome, Italy, 8-10 October 2014. https://doi.org/10.1109/EuRAD.2014.6991199

Blanchard, Y. (2021). Radar allemands de la Seconde Guerre: Les (bonnes) surprises de l'archéologie de terrain.

http://www.bunkers-saint-pabu.fr/wordpress/wp-content/uploads/2016/12/ARTICLE_ YVES-BLANCHARD.pdf

Blanchard, Y. (2021a). Manuscrit YB. Préparé pour l'ouvrage collectif “L'oeil de l'Atlantique".

C’Est en France (2020). Sémaphore de la Pointe du Raz (Phare du bec de Raz). 
http://www.cestenfrance.fr/semaphore-de-la-pointe-du-raz-phare-du-bec-de-raz/

Danzé, J., Le Berre, A., Le Bour, S., Morvan, J., \& Schavsinski, B. (2017). L'œeil de l'Atlantique. Imprimerie du Commerce.

Dupont, P. H., Fresil, Y., \& Tomezzoli, G. (2007). Deutsche Militärbauten bei Rennes. DAWA Nachrichten, 49, 56-66.

Farcy, O. (2012) Intérêt pour les chiroptères des bunkers de la Pointe du Raz à Plogoff. Bretagne Vivante. SEPNB-Societé Protection Nature Bretagne.

https://docplayer.fr/72654806-Interet-pour-les-chiropteres-des-bunkers-de-la-pointe-d u-raz-a-plogoff.html

Floch, A. (2012). L'Occupation Allemande dans les 141 Communes du Sud-Finistère. Cloitre.

Le Berre, A. (2020). Les installations radar allemandes de la pointe du Raz et leur environnement historique. https://polejeanmoulin.com/page27/

Lippmann, H. (2021). Funkmeß(ortungs)stellungen in Frankreich. Bretagne West mit Brest. http://www.atlantikwall.info/radar/france/rf_.htm\#Bretagne_West

Rudi, R. (1998). Typologie du Mur de l'Atlantique. Beetsterzwaag.

Tomezzoli, G., \& Dupont, P. H. (2011). Die Drehfunkfeueranlage Bernhard auf dem Mont Saint Michel de Brasparts. DAWA Nachrichten, 57, 4-15.

Tomezzoli, G., \& Marzin, Y. (2015). The Ero Vili and the Atlantic Wall. Advances in Anthropology, 5, 183-204. https://doi.org/10.4236/aa.2015.54018

Tomezzoli, G., \& Pottier, L. (2015). Die deutschen militärlogistischen Anlagen westlich von Mamers. DAWA Nachrichten, 65, 14-27.

Tomezzoli, G. T. (2017). The WW II German Stützpunkton the Menez-Hom (FinistèreFR). Archaeological Discovery, 5, 224-237. https://doi.org/10.4236/ad.2017.54013

Tomezzoli, G. T., \& Colliou, S. (2017). The WW II Saint-Pabu German Radar Camp and the Stützpunkte Re 03, Re 04. Archaeological Discovery, 5, 142-162. https://doi.org/10.4236/ad.2017.53009

Tomezzoli, G. T., \& Colliou, S. (2018). The WW II Saint-Pabu German Radar Camp-2. Archaeological Discovery, 6, 88-102. https://doi.org/10.4236/ad.2018.62006

Tomezzoli, G. T. (2019). The BDU West between WWII and Cold War. Archaeological Discovery, 7, 1-19. https://doi.org/10.4236/ad.2019.71001

Tomezzoli, G. T., \& Moser, J. -L. (2021). The German Radar Station La 318 Frosch. Archaeological Discovery, 9, 113-134. https://doi.org/10.4236/ad.2021.92006 


\section{Appendices}

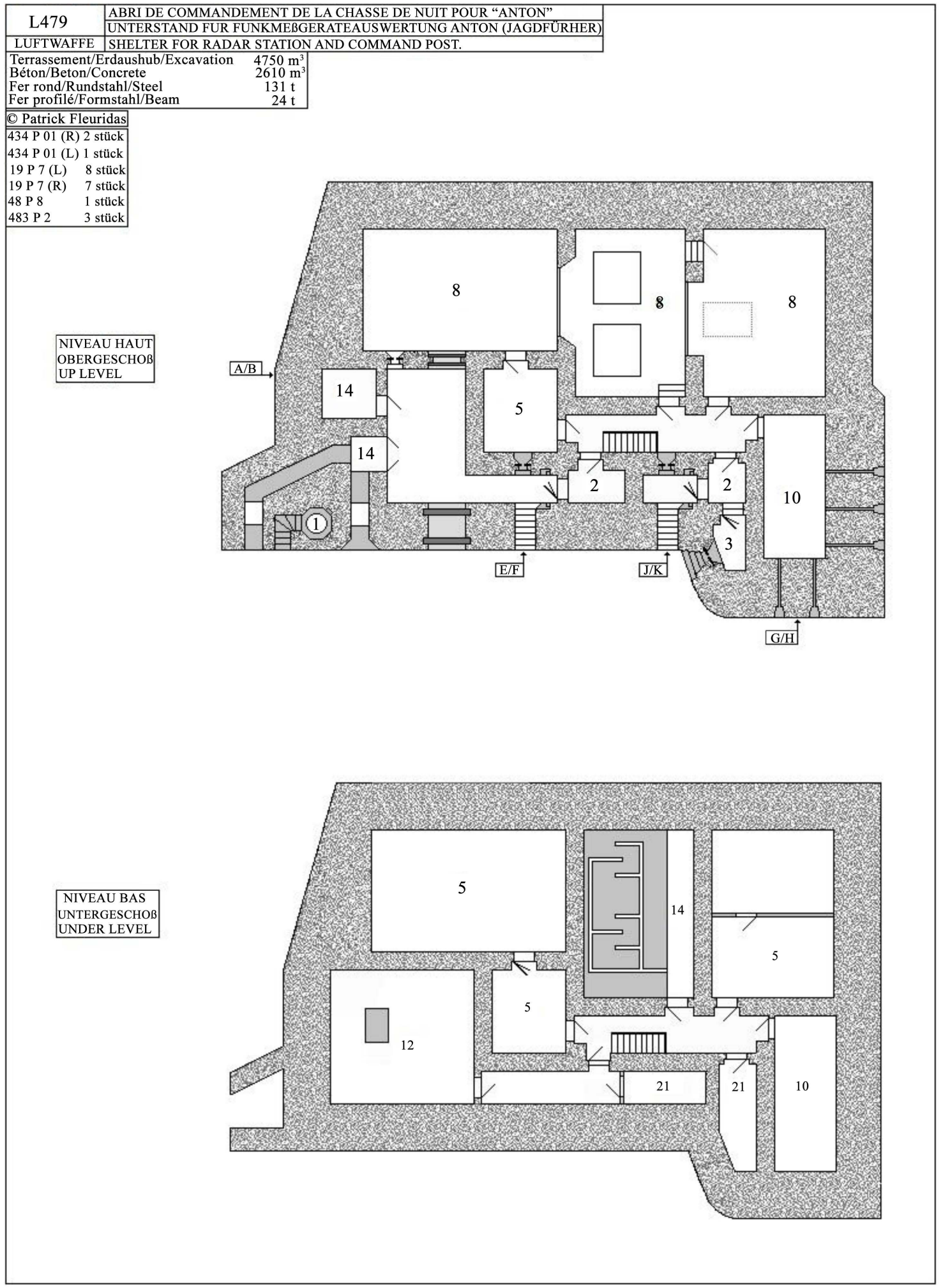

Figure A1. L 479 Anton shelter for radar station and command post-plan: 1 observation post; 2 gaslock; 3 close combat defence; 5 crew room; 8 command post; 10 wireless/telephone exchange; 12 ventilation; 14 command post; 21 store (Courtesy Fleuridas P.). 


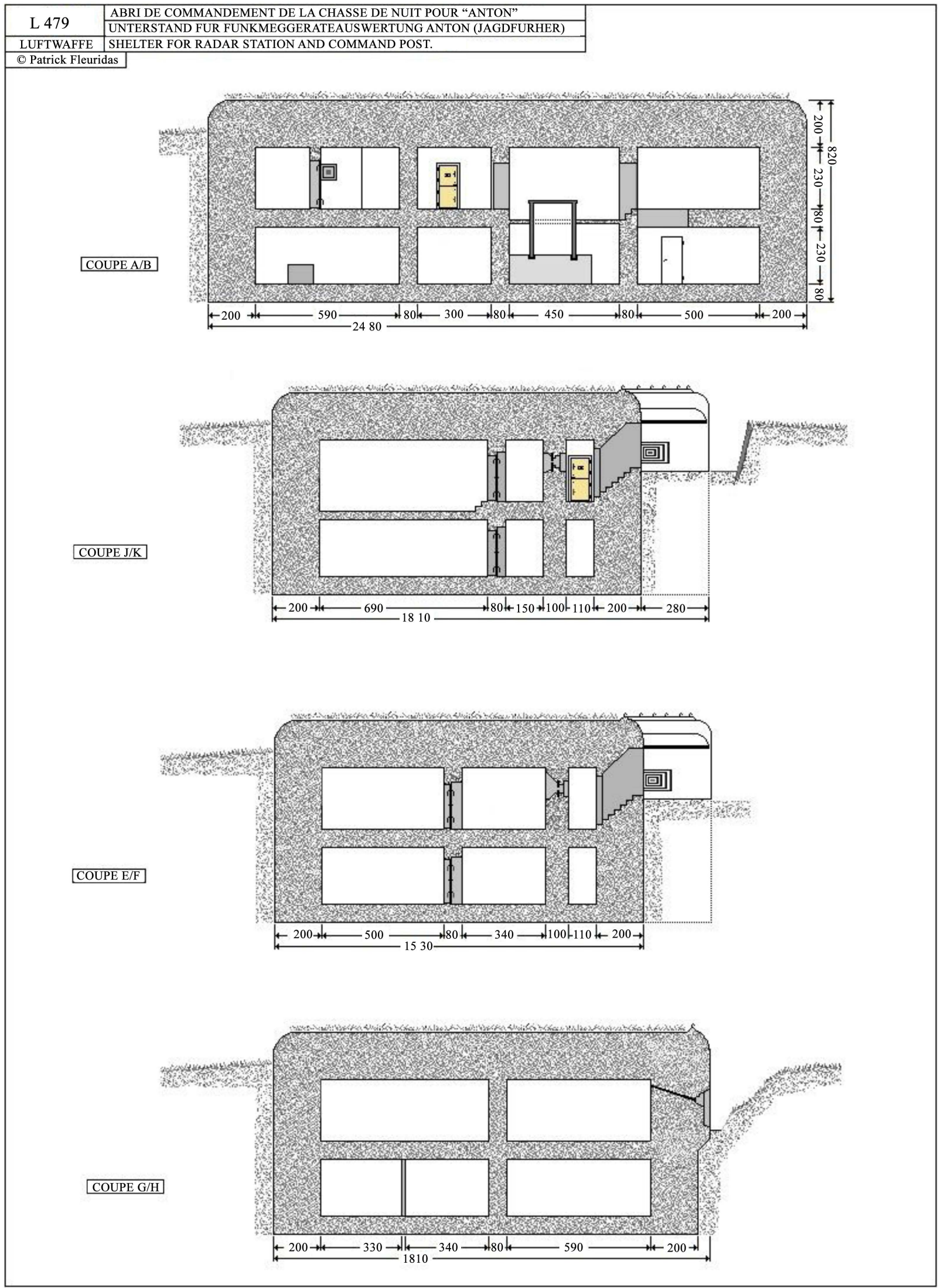

Figure A2. L 479 Anton shelter for radar station and command post-plan (Courtesy Fleuridas P.). 


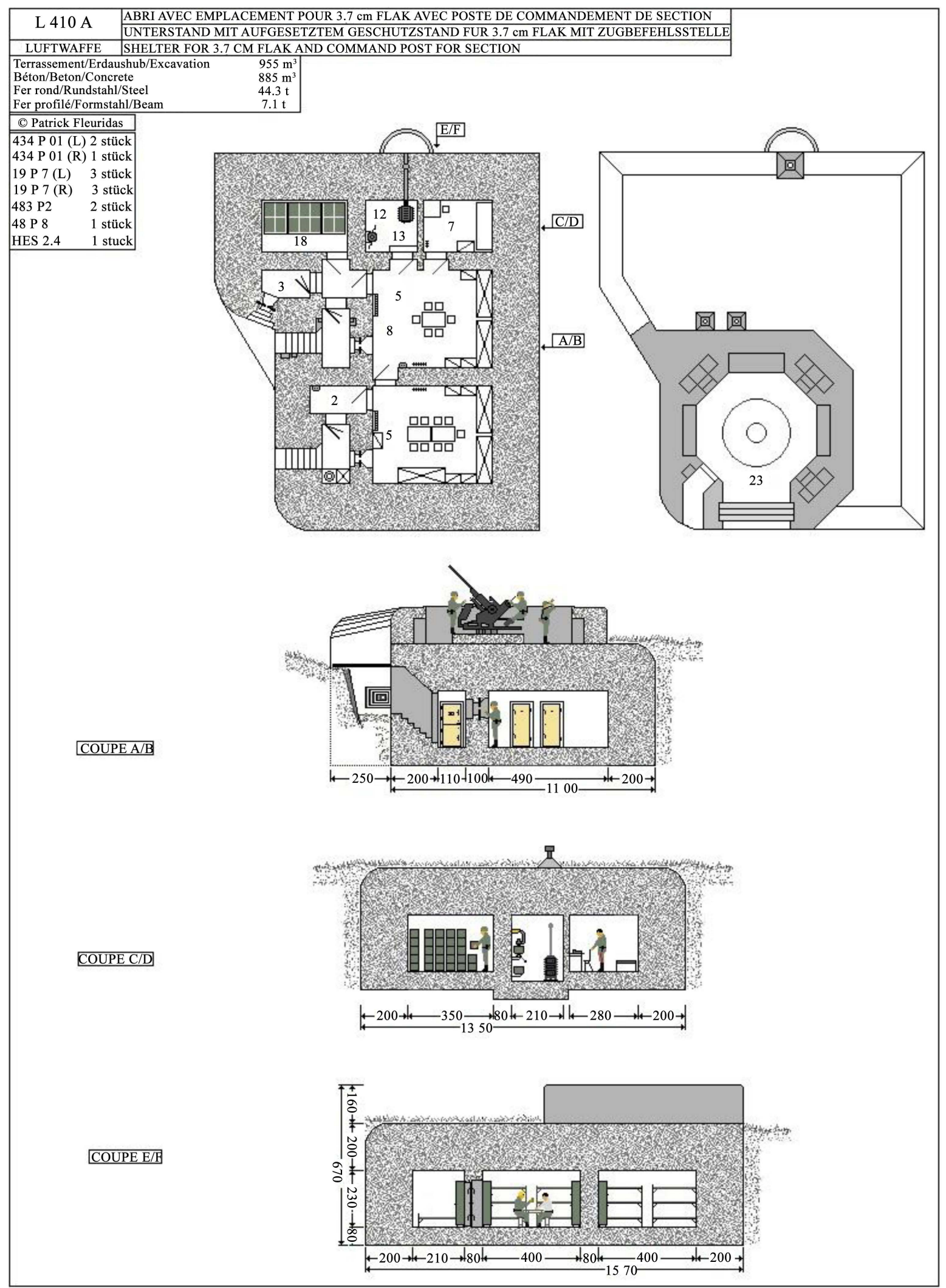

Figure A3. L $410 \mathrm{~A}$ shelter for $3.7 \mathrm{~cm}$ Flak and command section post-plan: 2 gaslock; 3 close combat defence; 5 crew; 7 non-commissioned officer; 8 close combat defence; 12 - 13 ventilation; 18 ammunition; 23 gun emplacement (Courtesy Fleuridas P.). 


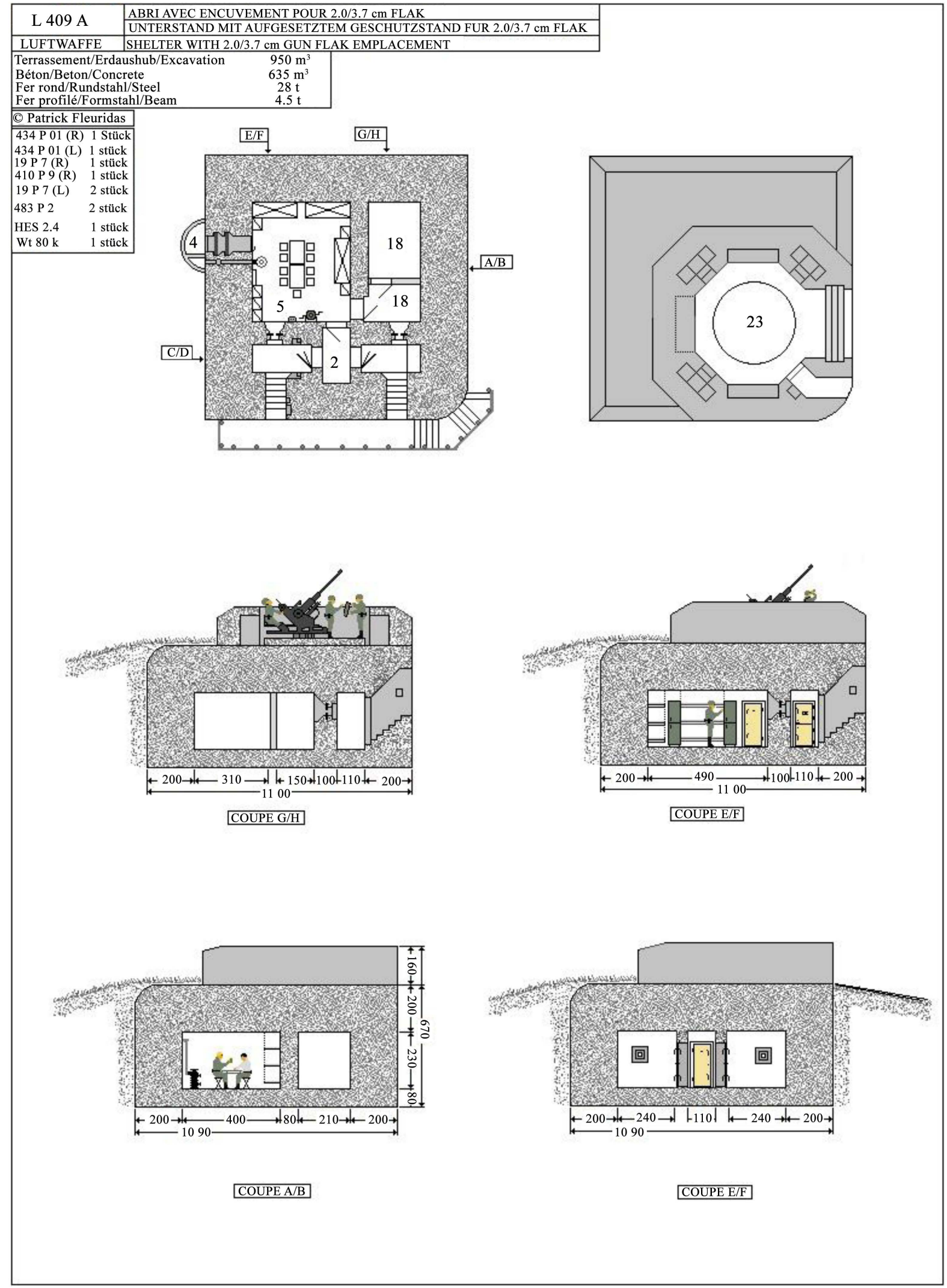

Figure A4. L 409A shelter for 2.0/3.7 cm gun Flak emplacement, plan: 2 gaslock; 4 emergency exit; 5 crew; 18 ammunition; 23 gun emplacement (Courtesy Fleuridas P.). 


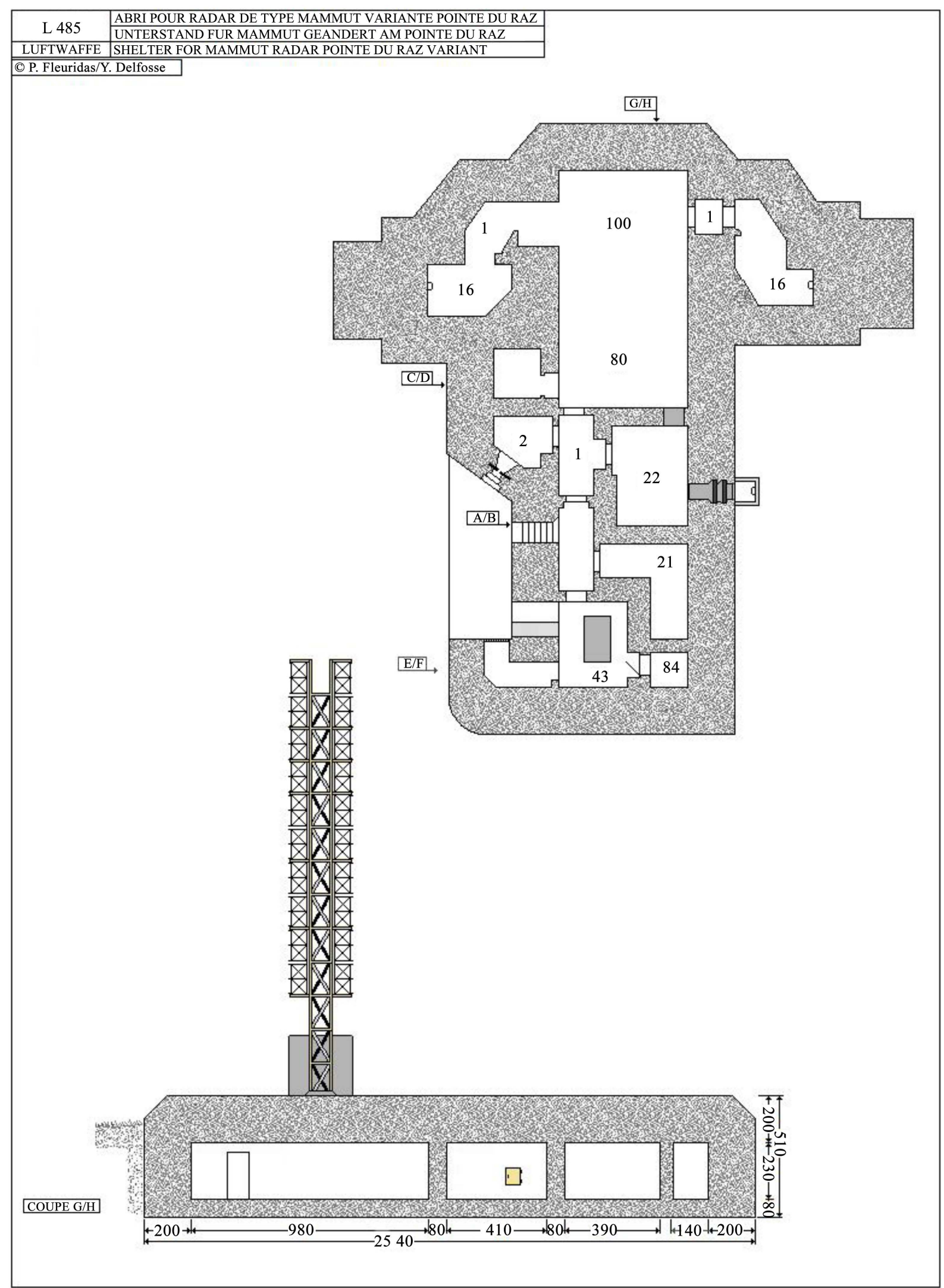

Figure A5. L 485 shelter for Mammut radar, plan: 1 gaslock; 2 close combat room; 16 antenna room; 21 heading; 22 ventilation; 43 engine room; 80 workshop; 84 recooling; 100 compensator (Courtesy Fleuridas P.). 


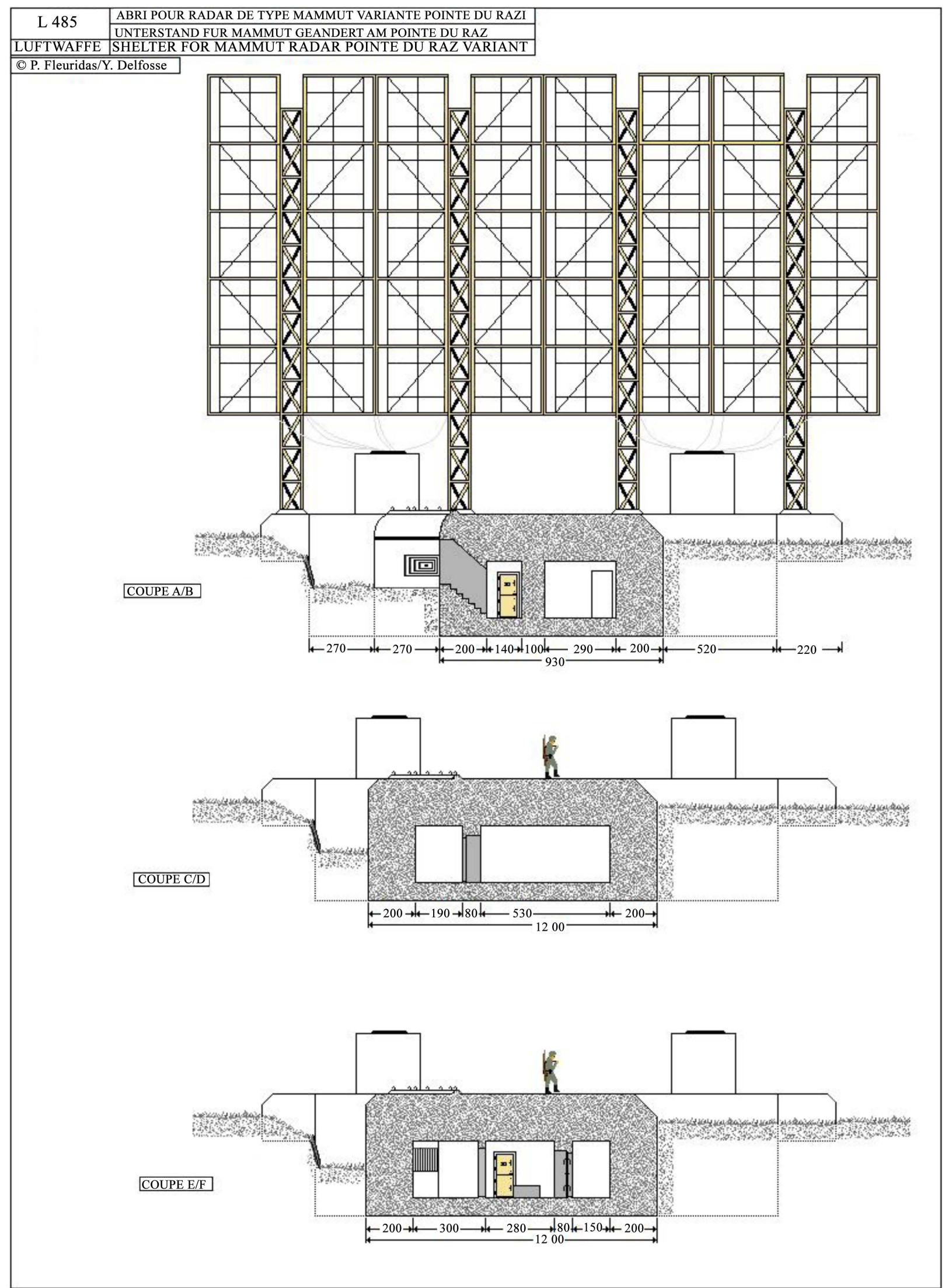

Figure A6. L 485 shelter for Mammut radar, plan (Courtesy Fleuridas P.). 


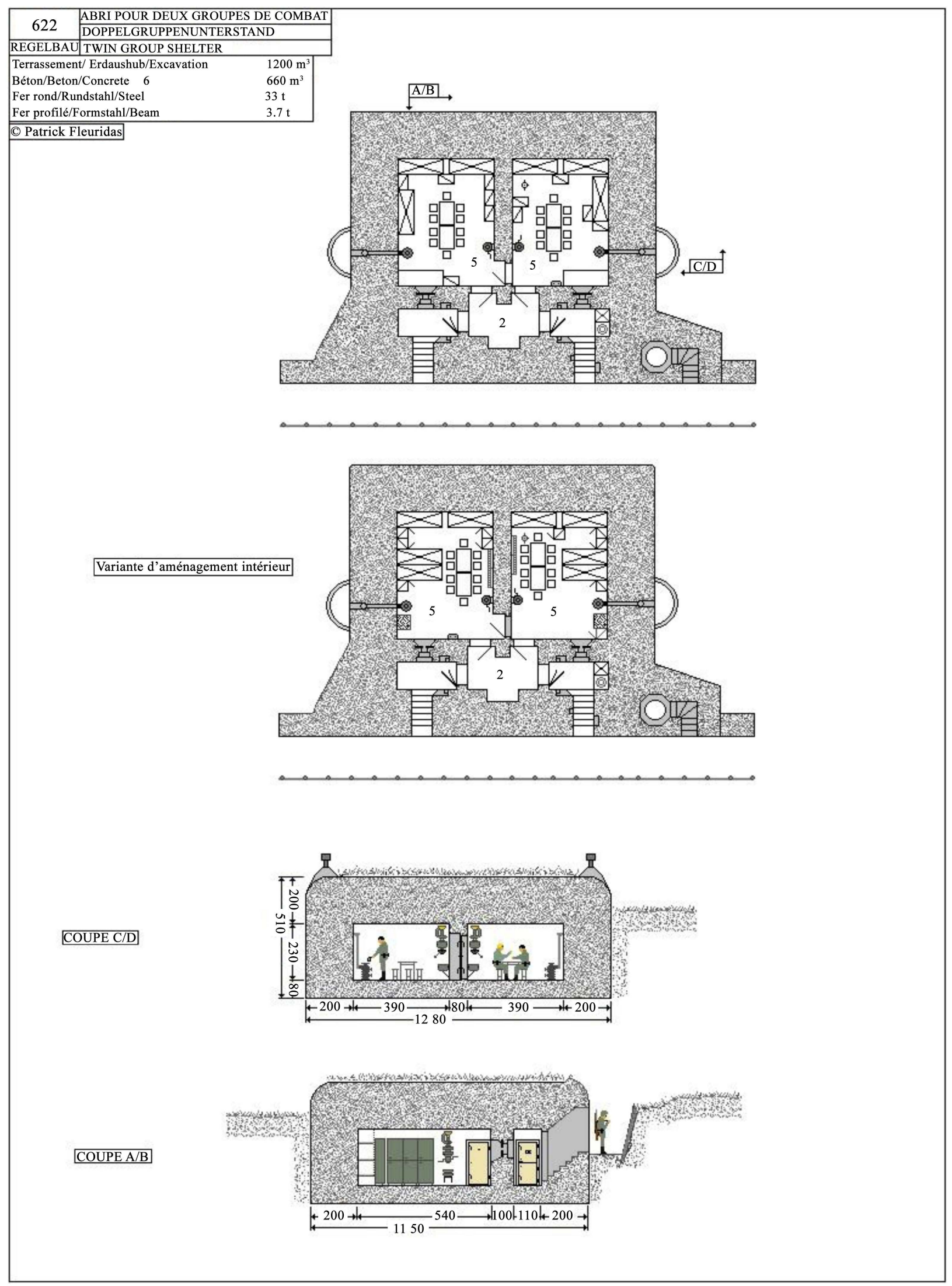

Figure A7. $R$ 622 twin group shelter, plan: 2 gaslock; 5 - 6 crew (Courtesy Fleuridas P.). 


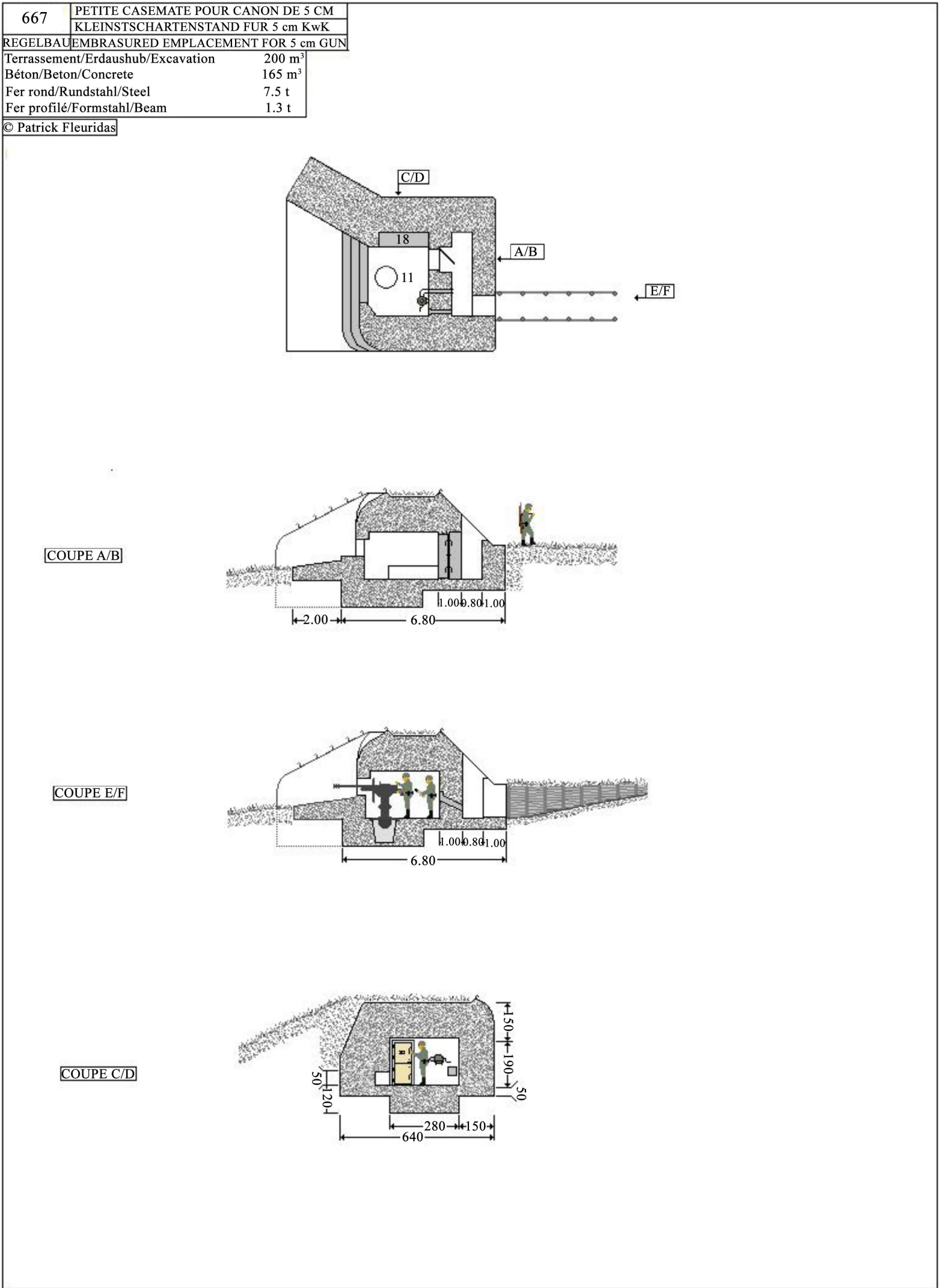

Figure A8. $R 667$ embrasured emplacement for $5 \mathrm{~cm}$ gun, plan: 11 combat room; 18 ammunition niche (Courtesy Fleuridas P.). 